Nat. Hazards Earth Syst. Sci., 19, 71-91, 2019

https://doi.org/10.5194/nhess-19-71-2019

(C) Author(s) 2019. This work is distributed under

the Creative Commons Attribution 4.0 License.

\title{
Landslides near Enguri dam (Caucasus, Georgia) and possible seismotectonic effects
}

\author{
Alessandro Tibaldi ${ }^{1}$, Paolo Oppizzi ${ }^{2}$, John Gierke ${ }^{3}$, Thomas Oommen ${ }^{3}$, Nino Tsereteli ${ }^{4}$, and Zurab Gogoladze \\ ${ }^{1}$ Department of Earth and Environmental Science, University of Milan Bicocca, Milan, Italy \\ ${ }^{2}$ Geolog, Chiasso, Switzerland \\ ${ }^{3}$ Michigan Technological University, Houghton, USA \\ ${ }^{4}$ M. Nodia Institute of Geophysics, M. Javakhishvili Tbilisi State University, Tbilisi, Georgia
}

Correspondence: Alessandro Tibaldi (alessandro.tibaldi@unimib.it)

Received: 24 June 2018 - Discussion started: 27 August 2018

Revised: 27 November 2018 - Accepted: 12 December 2018 - Published: 11 January 2019

\begin{abstract}
The Enguri dam and water reservoir, nested in the southwestern Caucasus (Republic of Georgia), are surrounded by steep mountain slopes. At a distance of $2.5 \mathrm{~km}$ from the dam, a mountain ridge along the reservoir is affected by active deformations with a double vergence. The western slope, directly facing the reservoir, has deformations that affect a subaerial area of $1.2 \mathrm{~km}^{2}$. The head scarp affects the Jvari-Khaishi-Mestia main road with offsets of man-made features that indicate slip rates of $2-9 \mathrm{~cm} \mathrm{yr}^{-1}$. Static, pseudostatic and Newmark analyses, based on field and seismological data, suggest different unstable rock volumes based on the environmental conditions. An important effect of variation of the water table is shown, as well as the possible destabilization of the slope following seismic shaking, compatible with the expected local peak ground acceleration. This worst-case scenario corresponds to an unstable volume on the order of up to $48 \pm 12 \times 10^{6} \mathrm{~m}^{3}$. The opposite, eastern slope of the same mountain ridge is also affected by wide deformation affecting an area of $0.37 \mathrm{~km}^{2}$. Here, field data indicate $2-5 \mathrm{~cm} \mathrm{yr}^{-1}$ of slip rates. All this evidence is interpreted as resulting from two similar landslides, whose possible causes are discussed, comprising seismic triggering, mountain rapid uplift, river erosion and lake variations.
\end{abstract}

\section{Introduction}

GPS data and plate tectonic models indicate that the Greater and Lesser Caucasus are tectonically very active, with ongoing mountain building processes comprising complex defor- mation with vertical and horizontal strain partitioning (Rebai et al., 1993; Koçyiğgit et al., 2001; Reilinger et al., 1997, 2006; Tan and Taymaz, 2006; Pasquaré et al., 2011). These processes result from the convergence and continent-continent collision that is still developing between the Eurasian and African-Arabian plates (Avagyan et al., 2010; Adamia et al., 2017) (Fig. 1). The active deformation is accompanied by diffuse seismicity that reaches $M_{\mathrm{s}}$ of 6-7 (Tsereteli et al., 2016) and intensity up to 10 (Varazanashvili et al., 2018) in the Caucasus in the Republic of Georgia.

In the southwestern part of the Georgian Greater Caucasus, the Enguri dam (the world's sixth highest dam) (Figs. 2 and 3a) and hydroelectric plant presently provide a major part of the energy to the country. The Enguri dam is located near a series of geological features that suggest Quaternary uplift, comprising deeply entrenched rivers, deformed river terraces, recent faults and folds and very steep slopes (Tibaldi and Tsereteli, 2017; Tibaldi et al., 2017a). The strategic importance of the Enguri hydroelectric plant and the fact that it is nested within one of the most tectonically active regions of the Caucasus suggest the necessity of carrying out modern studies on the stability of the slopes surrounding the water reservoir, $19 \mathrm{~km}$ long, which are completely missing in the scientific literature (only one technical consultant report exists, which is unpublished - CGS, 2015). Mountain slopes, in fact, are subject to gravity effects that can be enhanced by earthquake shaking (Gutierrez-Santolalla et al., 2005); it has been widely demonstrated that this shaking can cause the generation of shallow landslides and deep-seated gravity slope deformations (DSGSDs) in active seismic areas (Beck, 


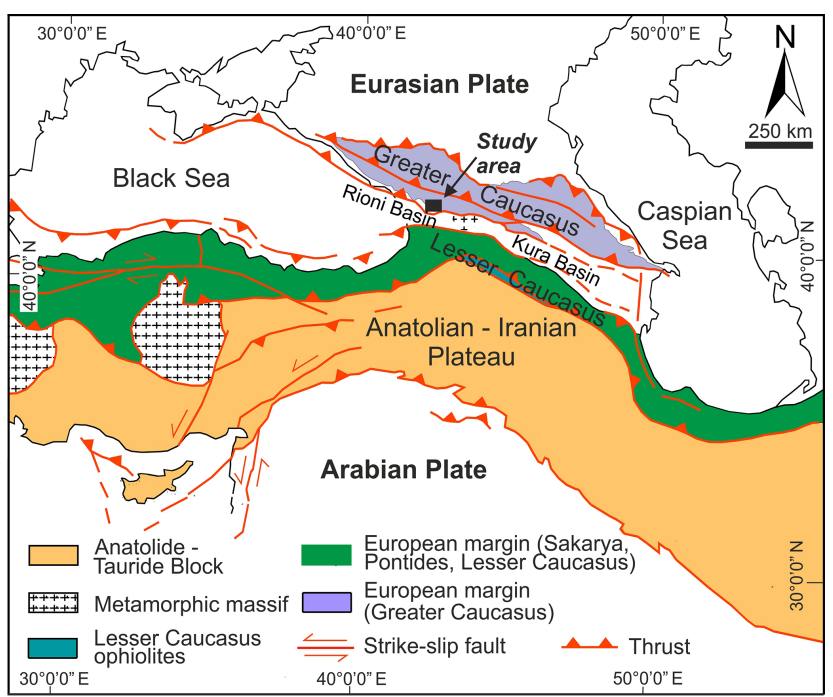

Figure 1. Tectonic map of the Arabia-Eurasia collision zone (modified from Sosson et al., 2010).

1968; Solonenko, 1977; McCleary et al., 1978; RadbruchHall, 1978; Tibaldi et al., 1995; McCalpin, 1999). The dynamic loading produced by seismicity may trigger discrete episodes of fast slope deformation (e.g., Beck, 1968) or may accelerate already existing movements along DSGSD structures (e.g., Pasuto and Soldati, 1996). Whether the movements are continuous (Varnes et al., 1989, 1990, 2000) or intermittent (Beget, 1985), the slopes under active deformation pose a threat to infrastructures (Mahr, 1977; RadbruchHall, 1978; McCalpin and Irvine, 1995). Near to the Enguri reservoir is the main road leading to the famous town of Mestia, hosting several ancient monuments and a ski resort. This road is affected by important slope deformations in correspondence with the same slope that faces the Enguri water reservoir. Moreover, in general, slope movements can turn into dangerous catastrophic collapses, examples of which have been reported in Japan (Chigira and Kiho, 1994), Italy (Semenza and Ghirotti, 2000) and Canada (Evans and Couture, 2002).

The present paper aims to describe, for the first time, the main active slope deformations affecting a mountain ridge that runs along the eastern side of the Enguri water reservoir. The approach is multidisciplinary since it comprises geological, geomorphological and structural surveys, completed with local seismic peak ground acceleration calculation and analyses of slope instability. The usefulness of similar multidisciplinary approaches has also been demonstrated, for example, by Sajinkumar et al. (2017). The focus of our work is to give the main piece of initial evidence that allows the boundaries of the unstable slopes, their geometries, kinematics, slip rate and volume to be defined. Field observations are completed by preliminary 2-D numerical static, pseudostatic and dynamic analyses. 3-D modeling requires further exten-

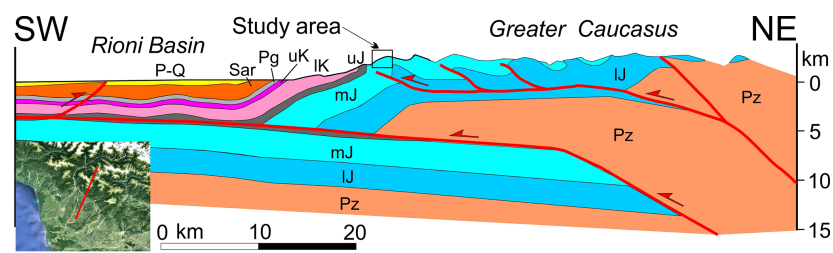

Figure 2. Structural section passing through the study area (box), obtained by integrating our field surveys with geophysical and geological data from Banks et al. (1997). Note the presence of a main basal thrust dipping north, which shows a ramp-flat geometry that produced a frontal asymmetric ramp anticline.

sive work that will be carried out in the future and deserves proper publication. The results show the presence of wide active slope deformations that affect the two opposite slopes of this mountain ridge.

The paper has a series of main international impacts: (i) it describes an outstanding example of intense gravity instability with double vergence, (ii) it contributes to answers to the challenging scientific questions on the causes of the increase in the instability of a slope facing a reservoir and (iii) it elucidates the regional processes that can contribute to the induction of intense slope instability. The paper also (iv) represents a contribution to assess the hydrogeologic hazard of the largest hydroelectrical facility of Georgia.

\section{Geological background}

The Greater and Lesser Caucasus are two fold-and-thrust belts separated by the Rioni Basin in the Black Sea and the South Caspian-Kura Intermontane Depression (Fig. 1) (Adamia et al., 1977, 2010; Banks et al., 1997; Mosar et al., 2010; Sosson et al., 2010). The Rioni and Kura regions first developed as foreland basins, in Oligocene-early Miocene times, and were successively affected by the fold-and-thrust belts, representing an example of intra-plate, fast-growing mountain building processes in Neogene times (Forte et al., 2010; Adamia et al., 2011; Alania et al., 2016). Faultbend folds and fault-propagation folds are widespread, with evidence of thin-skinned tectonics in both the Rioni and Kura fold-and-thrust belts (Adamia et al., 2010; Forte et al., 2010; Alania et al., 2016). These belts were subject to intense deformation during the last $14-15 \mathrm{Ma}$, characterized by an important fault slip along the main thrust systems that reached its greatest exhumation rate at the end of the Miocene (Adamia et al., 2017; Alania et al., 2016). These structural data are coherent with the results of apatite fissiontrack studies that revealed that the greatest exhumation rate occurred in the Miocene-Pliocene in the Greater Caucasus, although it started here in the Oligocene (Avdeev and Niemi, 2011; Vincent et al., 2007, 2011).

Successively, the mountain building processes continued up to the Quaternary as evidenced by geodetic and seis- 


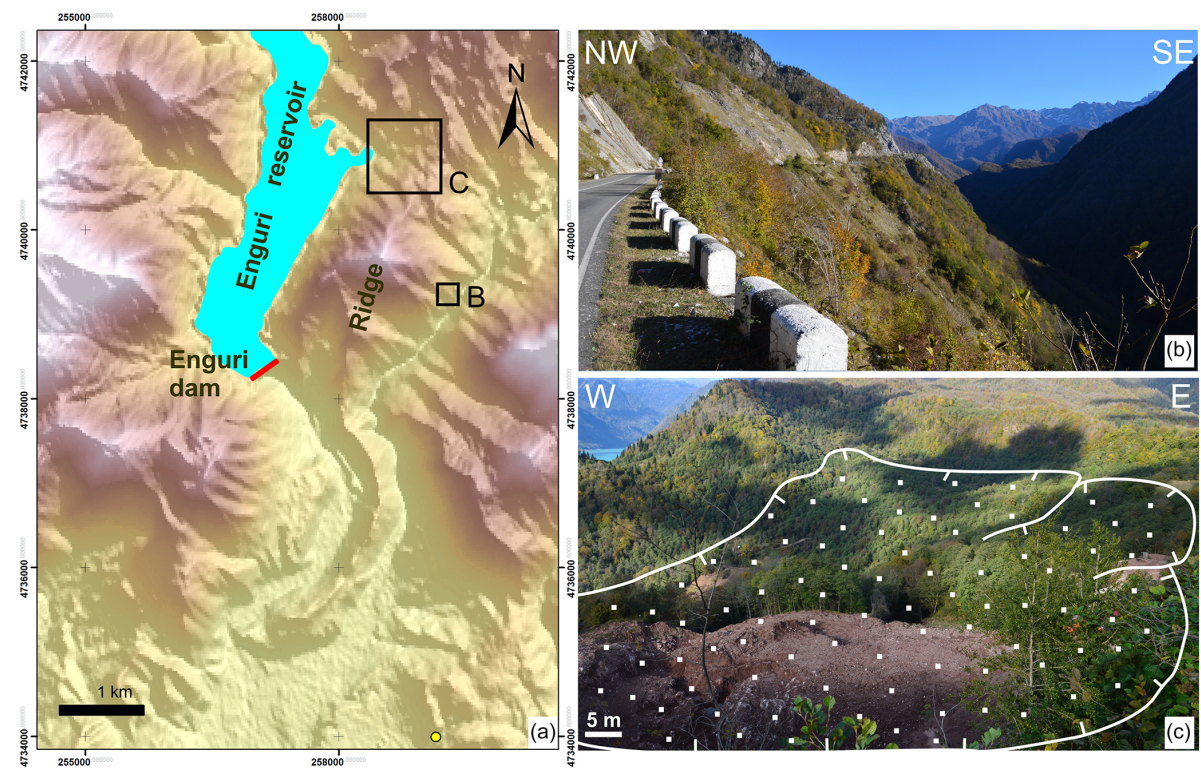

Figure 3. (a) DEM of the Enguri dam area. Boxes show the location of panels (b) and (c). (b) Segment of the Jvari-Khaishi-Mestia road where it crosses the eastern slope of the ridge highlighted in (a); here rocks and slopes are very steep, up to $70^{\circ} \mathrm{C}$. Oblique view (looking north) of the area, facing the Enguri water reservoir, affected by active slope deformation. The scale only refers to the forefront zone.

mic data (Tsereteli et al., 2016). More detailed historical and instrumental catalogues, seismic reflection sections, focal mechanism solutions and field geological-structural surveys show the presence of active compressional tectonics, both in the core of the Greater Caucasus and along the southern border and at the fold-and-thrust belts (Tsereteli et al., 2016; Tibaldi et al., 2017a, b). These authors showed that in the core of the Greater Caucasus there is a series of active reverse faults that are parallel to the mountain range (i.e., WNW-ESE). They dip mostly towards NNE and display pure dip slips. Along the southern front of the Greater Caucasus, where the Enguri dam is located, there is a zone of active thrusting along planes dipping towards NNE, as can be seen in the structural section portrayed in Fig. 2. This section has been obtained by integrating geological-structural field surveys from Tibaldi et al. (2017a) with geophysical and geological data from Banks et al. (1997). The section shows the presence of a main basal thrust dipping north. The basal thrust has a ramp-flat geometry that produced a frontal asymmetric ramp anticline corresponding to the area studied here.

The Transcaucasus depression, located between the Greater and Lesser Caucasus, shows active inversion tectonics in part of the Rioni Basin, with uplift, folding and faults mostly hidden under the youngest sedimentary cover (Tibaldi et al., 2017a, b). The largest instrumental and historical earthquakes, with $M_{\mathrm{S}} 6-7$, occurred both in the core of the two mountain belts and along their fronts. Hypocenters are mostly located at depths $<30 \mathrm{~km}$, with depths increasing eastward. A detailed new assessment of historical earthquakes of the whole of Georgia assigns intensity values of up to 10 to the Caucasus region (Varazanashvili et al., 2018). These data are consistent with geodetic observations by Reilinger et al. (2006), which indicate a total convergence rate of $2-3 \mathrm{~cm} \mathrm{yr}^{-1}$ between the plates located south and north of the Caucasus. The same authors suggest that about one-third of this convergence is accommodated along the Caucasus by crustal shortening. The total post-collisional subhorizontal shortening of this mountain belt caused by the northward motions of the African-Arabian plate is estimated at hundreds of kilometers (Barrier and Vrielynk, 2008; Meijers et al., 2013).

From a stratigraphic and lithological point of view, preMesozoic basement and Jurassic sedimentary rocks characterize the axial zone of the Greater Caucasus, whereas Cretaceous and Cenozoic sedimentary rocks are present in the more external zones (Adamia et al., 2011; Mosar et al., 2010). At the foot of the southwestern Greater Caucasus, where the Enguri dam is located, carbonatic deposits dominate together with rarer terrigenous and tuffaceous rocks of volcanic origin. More detailed data on the local geology are given below.

\section{Results}

\subsection{Local geology and geomorphology}

The studied area shows the presence of Jurassic volcanic and terrigenous rocks and Cretaceous carbonatic deposits generally dipping to the south (Fig. 4). Cretaceous strata crop out around the Enguri dam where they strike around E-W and dip mostly at $60-70^{\circ}$ towards S (Fig. 3b). They be- 


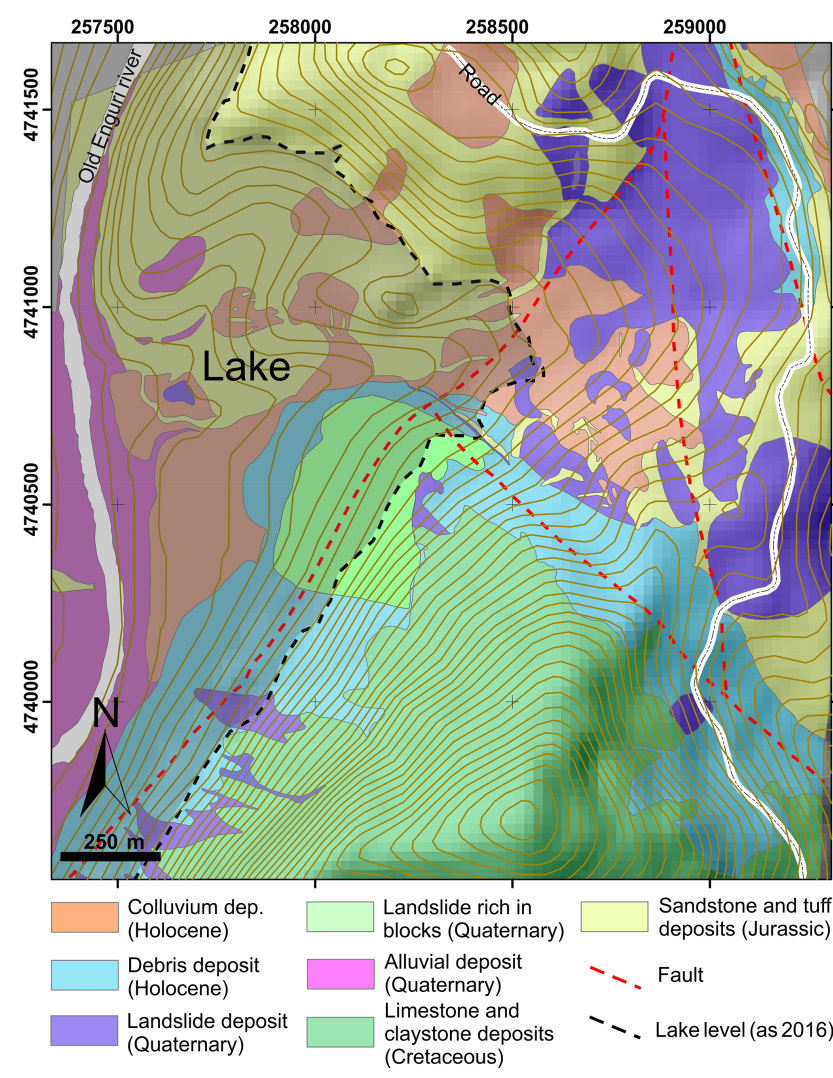

Figure 4. Geological map of the area surrounding the western landslide, based on our new field surveys in the onshore zone and data from Zolotarev et al. (1968) for the zone now submerged by the Enguri water reservoir.

come steeper southward, assuming a vertical dip near the Rioni plain, accompanied by local overturning of the strata with a steep dip to the north. Strata assume a gentler inclination northward, becoming subhorizontal towards the northern part of the Enguri reservoir. The region is affected by faults and folds that make the structural architecture locally more complicated. North of the Enguri dam, below the carbonatic strata, there are also Jurassic deposits made of sandstones, tuffs, tuff-breccia and gypsum layers that locally crop out along the southeastern side of the artificial water reservoir (Fig. 4). Their dip is again dominantly towards southeast and south, and generally becomes gentler northward, on the order of $15-40^{\circ}$.

From a geomorphological point of view, the studied area is characterized by the presence of two parallel river valleys trending about $\mathrm{N}-\mathrm{S}$ (Fig. 3a). The western valley hosts the Enguri dam, whereas the eastern valley is deeply entrenched, with differences of altitudes between the valley bottom and the mountain ridge of up to $700 \mathrm{~m}$. These two valleys are separated by a mountain ridge about $9 \mathrm{~km}$ long, whose western slope constitutes the side of the artificial water reservoir. The two opposite slopes of the mountain ridge are very steep, locally reaching up to an inclination of $70^{\circ}$, linked with

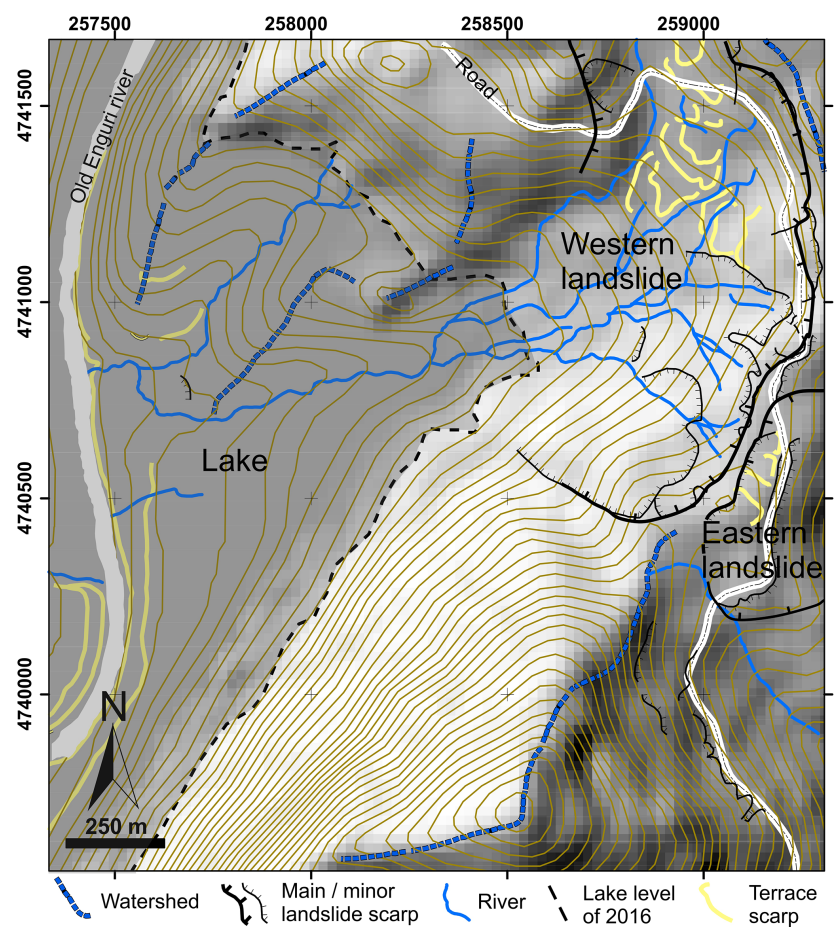

Figure 5. Geomorphological map of the area surrounding the western landslide, based on our new field surveys in the onshore zone and data from Zolotarev et al. (1968) for the zone now submerged by the Enguri water reservoir. The main head scarp of the other landslide facing east is also represented.

the presence of outcropping carbonatic rocks steeply dipping southward. The Jvari-Khaishi-Mestia main road runs along this mountain ridge and is under the threat of small landslides and, especially, of rolling stones at several sites, in particular where the road meets the outcropping steep rock strata (Fig. 3b).

This road is also affected by deformations related to the presence of the active head scarps of the two landslides that characterize the opposite slopes of the mountain ridge. The main head scarp of the landslide facing west, towards the Enguri reservoir, is represented in the upper part of Fig. 5. The head scarp of the other landslide is represented in the same figure on the slope facing east.

\subsection{Morphostructural field evidence of the western landslide}

The western slope of the mountain ridge faces the Enguri water reservoir directly. At a distance of about $2.5 \mathrm{~km}$ from the Enguri dam, this slope shows a series of landforms typical of recent and active deformation: along the Jvari-KhaishiMestia road, at an altitude of 720-740 m, there is a series of scarps facing westward (Figs. $3 \mathrm{c}$ and 5). They have a sinuous shape in plan view, given by anastomosed single scarps with a westward concave side. This suggests that these features resulted from the joining of a series of discrete head 

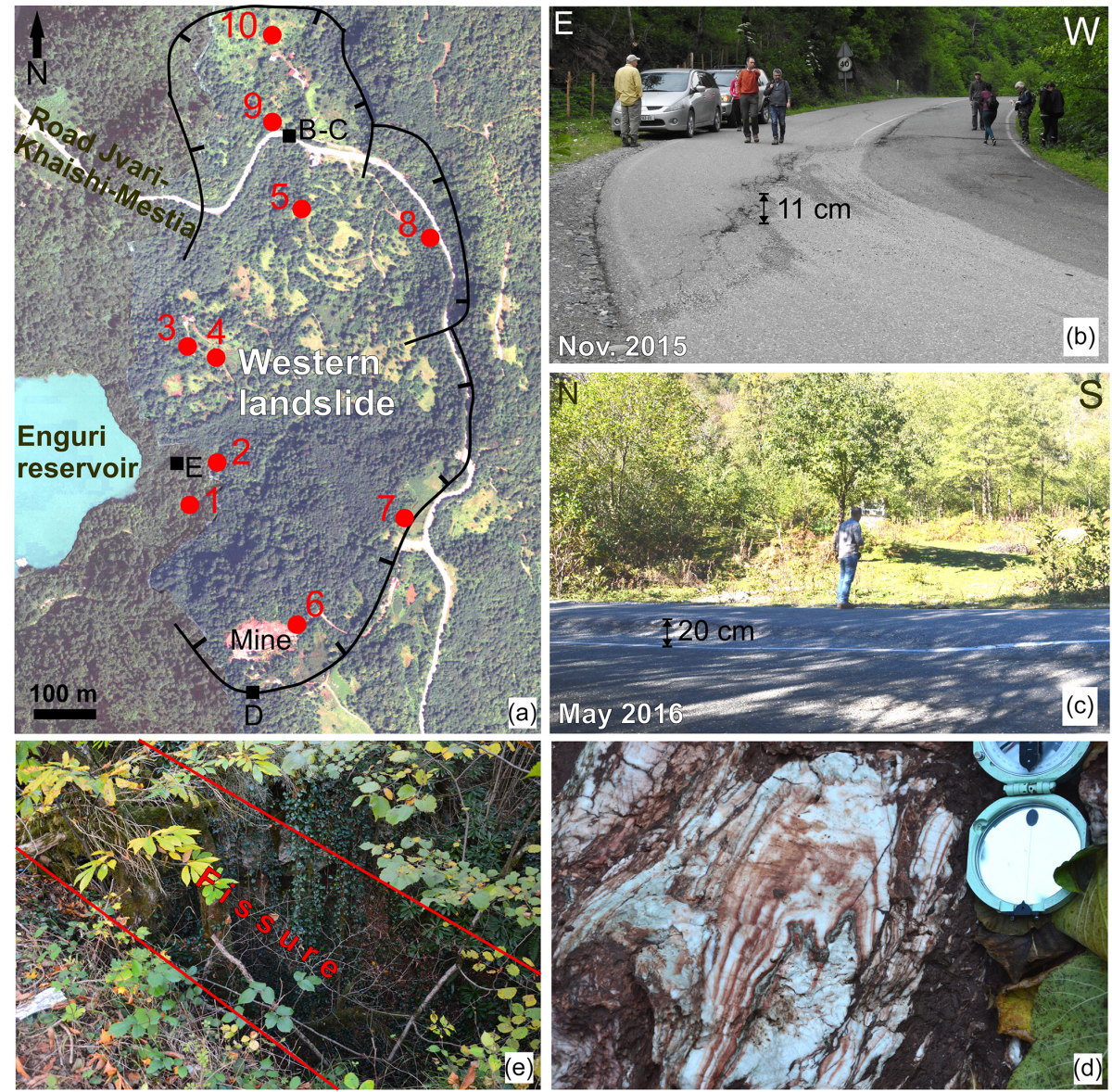

Figure 6. (a) Black lines show the main head scarps of the unstable slope area facing the Enguri reservoir. Black boxes show the locations of panels (b-e). Red dots show the location of piezometers discussed in the modeling section. Panels (b) and (c) show photos of one of the several slip planes that offset the Jvari-Khaishi-Mestia road, taken in November 2015 and May 2016, respectively; note the large increase of the offset. (d) Strongly deformed gypsum deposits located at the foot of the northern part of the unstable slope area. (e) NE-SW-striking fissure located at the head scarp of the southern part of the unstable slope area.

scarps. Each scarp is from a minimum of 20 up to $70 \mathrm{~m}$ high. At the scarp foot, the slope is from subhorizontal to gentle dipping westward (average inclination of $17^{\circ}$ ), whereas several changes of inclination are present along the slope. These changes are highlighted as terrace scarps in Fig. 5: they were checked in the field and do not correspond to man-made features. Most of these scarps are oriented perpendicularly to the local slope dip and are located in the upper part of the slope. These data suggest they may represent secondary ruptures within a moving slope. This is further confirmed by the presence of several tilted trees, with local zones where $100 \%$ of trunks are tilted, all along the area highlighted in Fig. 3c.

In regard to river streams, they have been outlined based on the present network and topographic maps surveyed before the formation of the water reservoir. Rivers mostly run along the average slope dip down to about half of the original slope, with a dendritic pattern (Fig. 5). At the lower half of the slope, now completely covered by the lake, one single river was draining the landslide area. A few river anomalies are present: at the foot of the slope, now under the lake, the lowermost segment of the aforementioned single river was running parallel to the main Enguri River but with a northward flow. In the northern, upper part of the slope affected by the landslide, one short river segment runs perpendicular to the average slope dip. These river diversions may correspond to anomalies in the average slope topography.

In regards to fractures and fissures, these affect the whole area close to the head scarps (Fig. 6a). The asphalted surface of the Jvari-Khaishi-Mestia road is affected by several offsets: deformation is represented by fissures, up to a few centimeters wide, and scarps facing westwards (Fig. 6b and c). These structures are parallel to subparallel to the morphological head scarps. The scarps offsetting the road were repeatedly measured from November 2015 to May 2017, showing that the vertical component of the offset developed up to $14 \mathrm{~cm}$ during this time frame, giving an average slip rate of $9.3 \mathrm{~cm} \mathrm{yr}^{-1}$ at the northernmost structure. As an example, in Fig. 6b we report the northern scarp surveyed in Novem- 


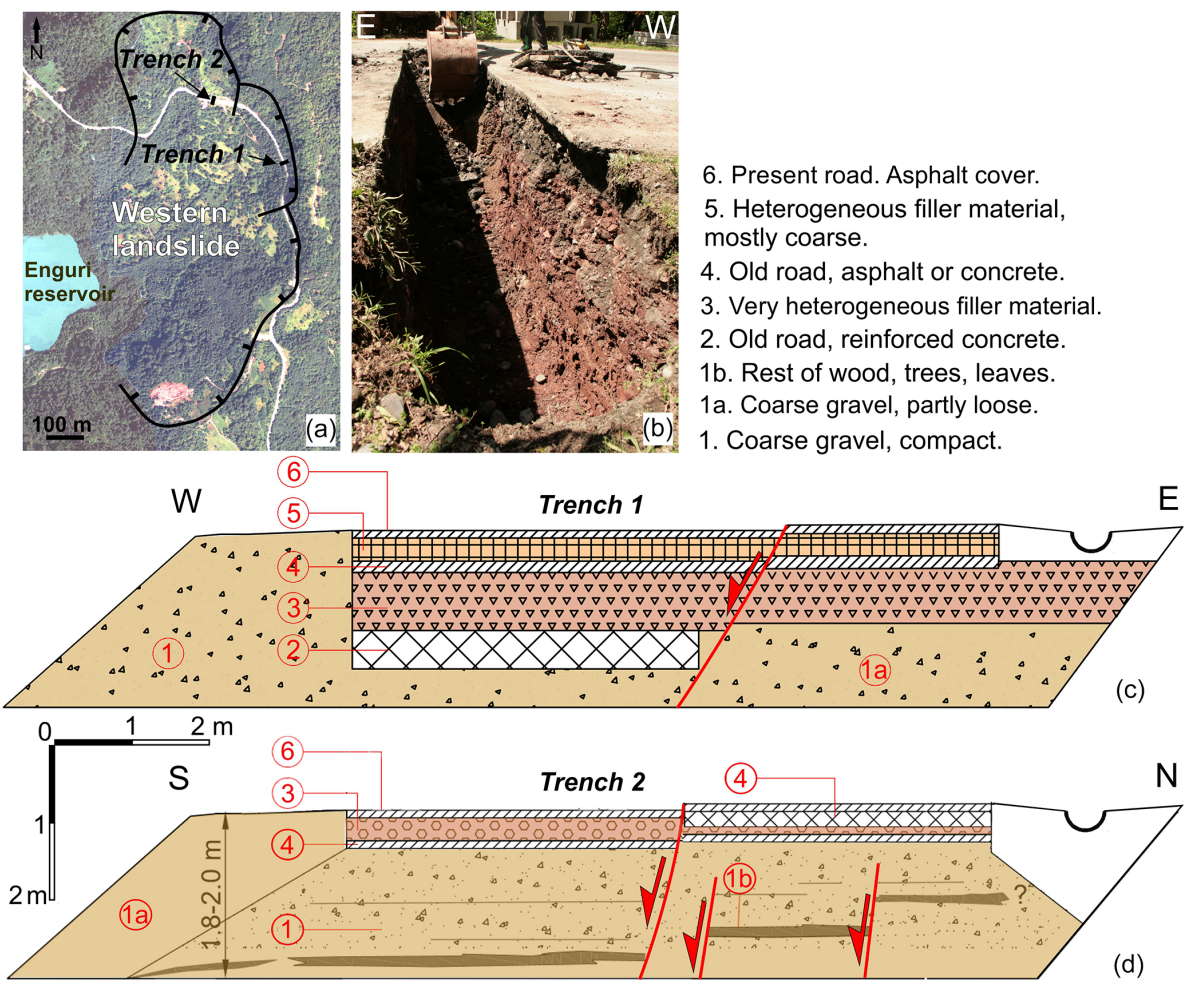

Figure 7. (a) Location of the trenches at the northern part of the unstable slope facing the Enguri reservoir. (b) Photo of Trench 2 opened across one of the main active scarps affecting the Jvari-Khaishi-Mestia road; the location is shown in (a). Panels (c) and (d) show logs of the northern and western walls of Trench 1 and 2, respectively. Numbers refer to the legend. Present and old, offset roads are white. The oldest road is downthrown to the west by $1.3 \mathrm{~m}$. The red lines show the location of shallow active slip planes.

ber 2015 , which was $11 \mathrm{~cm}$ high; the same scarp then increased to $20 \mathrm{~cm}$ in May 2016 (Fig. 6c).

In the southern segment of the head scarps, a detailed survey in the forest showed the presence of fissures, tens of meters long and up to $3.8 \mathrm{~m}$ wide (e.g., Fig. 6d). All the fissures are vegetated and mostly filled, with the local presence of trees grown inside the fissure, with trunks of about $20 \mathrm{~cm}$ in diameter. The bottom of the fissures is filled by coarse debris and soil, while the empty upper part of the fissures has a depth in the range of $1-3 \mathrm{~m}$. This suggests that these fissures have a long history, at least of some decades. The area at the foot of this fissure swarm is locally known as the Khoko landslide. Presently, gypsum is excavated here at a small open mine for economic reasons (Fig. 6a). At the foot of this landslide, near the coast of the artificial water reservoir, we recognized the presence of intensely deformed gypsum rocks (Fig. 6e).

We opened two trenches across some of the main active scarps affecting the Jvari-Khaishi-Mestia road (Fig. 7). The trenches show evidence of repeated downthrow of the western block. The western part of Trench 1, in fact, contains two buried old road surfaces: the oldest is lowered by $1.3 \mathrm{~m}$ with respect to the present road level, whereas the second one is lowered by $20 \mathrm{~cm}$ (Fig. 7c). Interviews with local inhabitants indicated that the oldest road was built during the Soviet era, about $1960 \mathrm{CE} \pm 5$ years. Although we are aware that the Soviet road was narrower than the present one, the presence of filling material between the various road levels indicates that subsidence did occur here since it was necessary to restore the road plane level. Also nowadays, in fact, continuous road maintenance is necessary here, with tens of centimeters of asphalt added above the downhill segment of the road surface to maintain the level. Trench 2 also contains two buried roads, plus a layer of collapsed trees and pieces of wood that is offset by several slip planes dipping downslope (Fig. 7d).

The total subaerial area affected by slope deformation is $1.2 \mathrm{~km}^{2}$. The slip surface is not unique and there are probably different, partially superimposed slip planes, as suggested by the complexity of the head scarps and of the slope morphology, and the dimension of the whole unstable slope. All the piezometers installed during 2015 across the landslide body are broken at depths between 16 and $49 \mathrm{~m}$, as can be appreciated by comparing columns 6 and 8 in Table 2 . These widespread ruptures should correspond to the depth of some active slip planes. Other logs also drilled during the Soviet era (see Sect. 3.4) suggest that the intact substrate rock is located at deeper levels. This can be seen, for example, in logs no. 3261 and 3297 (drilled in 1966) (Fig. 8). These logs show the presence of clastic, unconsolidated deposits, rich in clay and local gypsum fragments, down to a depth of $57.5 \mathrm{~m}$ 


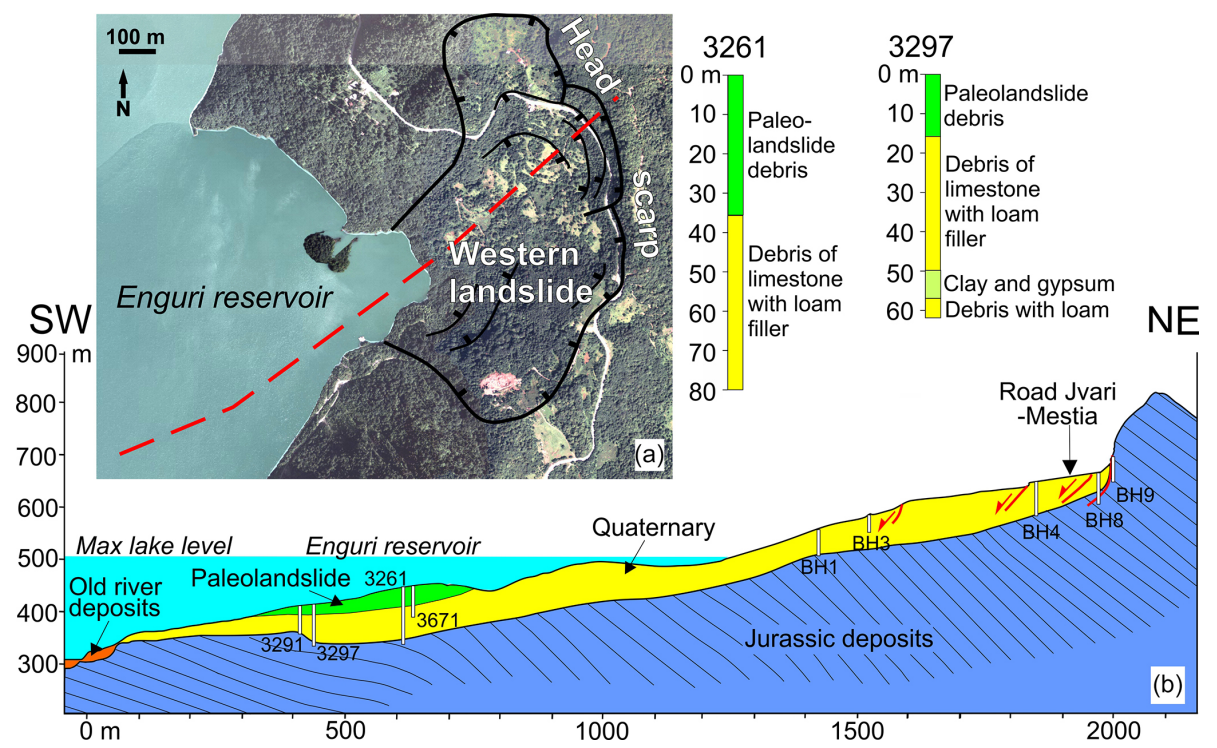

Figure 8. (a) Trace (red line) and (b) geological section across the slope facing the Enguri reservoir. White columns represent locations and depth of logs used to construct the cross section. Data of the submerged part, derived from geological surveys conducted in the Soviet era before dam construction, are shown. Two examples of detailed logs (3261 and 3297) are given.

( $\log 3297)$, and/or clastic deposits with a sill to clay matrix down to at least $61 \mathrm{~m}(\log 3297)$ and at least $80 \mathrm{~m}(\log 3261)$. Other logs, such as no. 3291 (drilled in 1966), indicate clay and gypsum deposits down to a depth of $30 \mathrm{~m}$, below which is the substrate. These observations, together with detailed geological and geomorphological surveys, allowed us to prepare the geological vertical section shown in Fig. 8b, which in turn is the base to construct the geotechnical section used for slope stability analyses. The geological section indicates that the intact substrate rock is located at a variable level, always deeper than $30 \mathrm{~m}$ and locally even $>80 \mathrm{~m}$.

\subsection{Field evidence of the eastern landslide}

The east-facing slope of the same mountain ridge described above is also affected by active deformations (Figs. 9 and 10). Here, the Jvari-Khaishi-Mestia road, at an altitude of $715-720 \mathrm{~m}$, is characterized by a series of fractures with two main orientations: one set is parallel to the road; i.e., it follows the topographic contour lines with a $\mathrm{N}-\mathrm{S}$ strike. The other fracture set strikes about E-W, perpendicular to the slope.

Most N-S-striking fractures show evidence of extension, with horizontal and vertical offsets of several centimeters of the road surface. The N-S fractures follow an escarpment that runs along part of this east-facing slope for a total length of about $450 \mathrm{~m}$. The height of this scarp is on the order of 3-20 m. At the southern end of the escarpment, the road has deformations with lower amounts of offset. At the foot of the head scarp there is a lake, measuring $43 \mathrm{~m} \times 17 \mathrm{~m}$, with the long axis parallel to the local scarp strike (Fig. 10). The lake is associated with local thick clay deposits that require time for their formation. Where the head scarp of the landslide comes closer to the head scarp of the other western landslide, there is a series of long and wide fissures in the densely vegetated forest (e.g., Figs. 6d and 10). These fissures host several tree trunks whose dimensions suggest they are at least some decades old.

The fractures striking E-W show dominant left-lateral strike-slip motions on the order of several centimeters of the road surface (e.g., Fig. 9b). A secondary, local extensional (vertical) component is also present. The resulting net slip indicates left-lateral transtensional motions. An old, N-Strending concrete wall, located along the head scarp, is tilted $5^{\circ}$ towards north (Figs. 9c, d). It is also left-laterally offset by $190 \mathrm{~cm}$, as measured in November 2015 , and $195 \mathrm{~cm}$, as measured in May 2017 (Fig. 9e). Nearby, a recent road water channel was also left-laterally offset by $5 \mathrm{~cm}$ during a November 2015 measurement (Fig. 9f), which increased to $7 \mathrm{~cm}$ in May 2017. These offset man-made features are aligned with an offset white strip painted on the asphalt of the Jvari-Khaishi-Mestia road (Fig. 9b). The white strip shows a left-lateral offset of $8 \mathrm{~cm}$. Interviews with local inhabitants and authorities gave indication of an age of 1974 CE for the concrete wall, whereas the white strips were painted 2 years before we obtained the offset data.

The total area affected by slope deformation is $0.37 \mathrm{~km}^{2}$. In this area, the lack of drillings did not allow us to assess the possible depth of the main slip surface. A simple projection of the possible depth of potential slip surfaces allowed us to speculate about a possible range of volume of the total unstable mass of $40 \pm 7 \times 10^{6} \mathrm{~m}^{3}$. Anyway, we wish to stress that this estimate must be confirmed by further studies. 

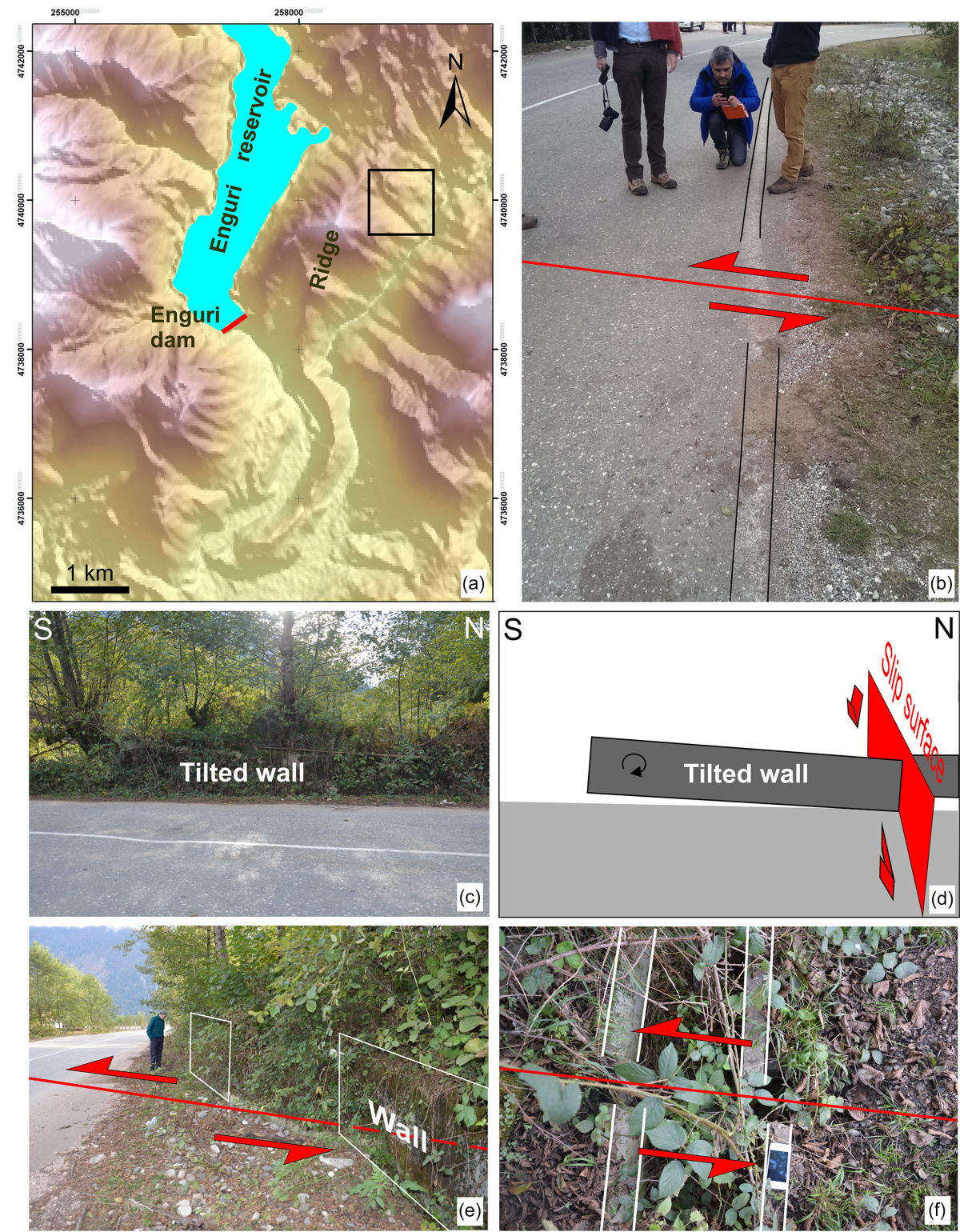

Figure 9. Features observed of the eastern landslide, located in the box shown in (a). (b) Left-lateral offset of the Jvari-Khaishi-Mestia road white strip. (c, d) Photo and interpretation of the tilted wall along the same road. (e) Left-lateral offset of $1.9 \mathrm{~m}$ of a $1974 \mathrm{CE}$ wall. (f) Left-lateral offset of a recent water channel.

\subsection{Slope stability analyses}

To assess the stability of the slope, the depth of the possible slip surfaces and the contribution of the water table and its variation, comprising different lake levels, and to gauge the impact of possible seismic shaking, we developed a series of analyses of the western landslide; we used the program Rocscience 7.024, with the approaches of Janbu and Morgenstern-Price, for static conditions, whereas for seismic stability evaluation, we employed pseudostatic analysis and Newmark modeling.
The slope stability analyses have been carried out based on a geological-geotechnical model that takes data from our field surveys, geotechnical tests and logs drilled during the Soviet era (1966) and by CGS (2015) into account. The logs of 1966 are located in the lower slope, between 343 and $546 \mathrm{~m}$ a.s.l., in part corresponding to the area now under the lake level; the more recent logs are located between 566 and $727 \mathrm{~m}$ a.s.l. (Fig. 8b). The reconstruction of the stratigraphy of the landslide zone has been done by merging our field surveys with data from the logs no. 3291 (done in 1966), located at $403.62 \mathrm{~m}$ a.s.l., no. 3297 (1966) at $418.87 \mathrm{~m}$ a.s.l., no. 3261 (1966) at 435.62 ma.s.l. and no. BH1, BH3, BH4, BH5 and 
Table 1. Geo-mechanical properties of the deposits. The final material properties used for the modeling are presented in bold.

\begin{tabular}{|c|c|c|c|c|}
\hline Rock/deposit & Friction angle $\left(\varphi^{\prime}\right)$ & Cohesion $\left(c^{\prime}\right)$ & Specific weight $(\gamma)$ & Data source \\
\hline Clay, measurements in borehole & $10-18^{\circ}$ & $20-47 \mathrm{kPa}$ & $19.4-20.1 \mathrm{kN} \mathrm{m}^{-3}$ & (1) \\
\hline $\begin{array}{l}\text { Clay, collected at depth } 16-17 \mathrm{~m} \text { (SH2) } \\
\text { and 51-51.2 } \mathrm{m} \text { (SH4) }\end{array}$ & $16-18^{\circ}$ & $44-47 \mathrm{kPa}$ & $19.2-19.5 \mathrm{kN} \mathrm{m}^{-3}$ & (1) \\
\hline $\begin{array}{l}\text { Weathered bedrock (heavy fractured rock } \\
\text { with loam-clay filling) }\end{array}$ & $32^{\circ}$ & $50 \mathrm{kPa}$ & $22 \mathrm{kN} \mathrm{m}^{-3}$ & (2) \\
\hline Coarse clastic deposit & $35-45^{\circ}$ & $0 \mathrm{kPa}$ & $22-23 \mathrm{kN} \mathrm{m}^{-3}$ & (2) \\
\hline Intact bedrock & $35^{\circ}$ & $200 \mathrm{kPa}$ & $25 \mathrm{kN} \mathrm{m}^{-3}$ & (2) \\
\hline Shallow deposits & $16^{\circ}$ & $0.01-10 \mathrm{kPa}$ & $19.65 \mathrm{kN} \mathrm{m}^{-3}$ & (3) \\
\hline Bedrock & $32^{\circ}$ & $200 \mathrm{kPa}$ & $23.5 \mathrm{kN} \mathrm{m}^{-3}$ & (3) \\
\hline
\end{tabular}

${ }^{1}$ Geotechnical Laboratory Tbilisi. ${ }^{2}$ Field observations and Hoek and Bray (1981). ${ }^{3}$ Back analysis and field observations.

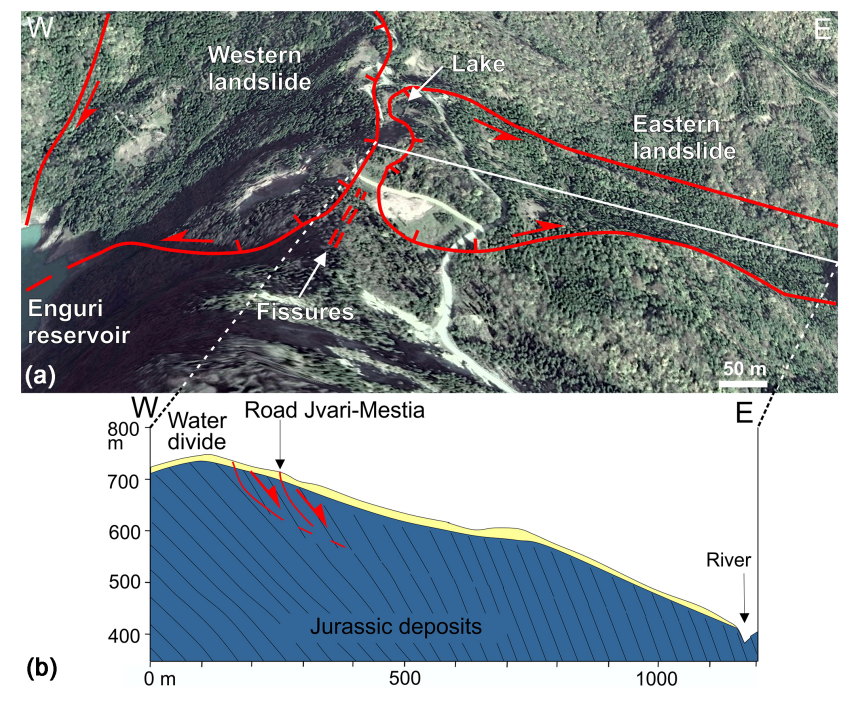

Figure 10. (a) Location of the main boundary scarps of the two landslides. Note the small lake at the foot of the head scarp of the eastern landslide, and the fissures located between the head scarps of the two landslides (oblique view from Google Earth). (b) Geological section along the eastern landslide; the trace is shown by the white line in the figure above.

BH6 (done in 2015) located at 570-693.7 m a.s.1., and surveys conducted by Soviet researchers previous to the dam construction.

The present outcropping substrate consists of Jurassic volcano-sedimentary rocks, with interlayering of tuff deposits and sandstones, mostly dipping E to NE (Fig. 8). The same rocks and bedding attitude were surveyed at the foot of the slope before the dam construction. These rocks are locally covered by Quaternary landslide and slope debris deposits. Based on their geotechnical characteristics, the succession has been divided into two geotechnical members: the deepest unit (in brown in Fig. 11) is given by the more intact tuffs and sandstones located below the surface located at a depth between 30 and $80 \mathrm{~m}$. Above this surface, we consid- ered a second geotechnical unit (in green in Fig. 11) made of clay, gypsum, debris and old landslide deposits. Debris contains dominant sandstones and tuff fragmented rocks, with a loam matrix, more rarely a clay matrix, rich in carbonatic and gypsum fragments. Locally, carbonatic fragments dominate. The thickness of this unit is from a few meters to a maximum of $80 \mathrm{~m}$. These two units are covered by late Quaternary deposits that comprise colluvium, eluvium and shallow debris, with a thickness from 1 to $5 \mathrm{~m}$. These shallow deposits have been incorporated in the second geotechnical unit (green unit), due to their low thickness and spatial variability. The geomechanical-geotechnical parameters obtained for the materials affected are presented in Table 1. Considering the high variability of deposits and thus of material properties, we performed a back analysis of the landslide to determine the appropriate material properties.

Figure 6a locates the piezometric wells that have been used to locate the depth of the water table. Our survey of piezometers showed the presence of water that reached the topographic surface during May 2017 (Table 2). In one well (BH9), the water table showed a temporary artesian behavior. The variation of the Enguri reservoir water level was established based on the information received from the Enguri Dam Company, which indicated the range $430-510 \mathrm{~m}$ a.s.l. Taking into account the low hydraulic conductivity of part of the deposits composing the studied slope, the large variations of lake level and the intense rains that characterize this region, we focused on slope stability analyses that consider the stage of saturation of the deposits affected and did not carry out a transient slope stability analysis. The final material properties used for the modeling were derived based on back analysis and field observations and are presented in bold in Table 1. In particular, the values of cohesion used take into consideration the widespread presence of clastic debris deposits locally with abundant silty clays.

In the first static model, the reservoir water level is taken fixed at the maximum level (510 m) (Fig. 11a). The table water level inside the landslide body is assumed to be characterized by complete saturation as indicated by piezometers 
Table 2. Location of measured piezometers and water table depth; b.g.s. refers to depths below ground surface.

\begin{tabular}{|c|c|c|c|c|c|c|c|}
\hline Site & $\begin{array}{r}\text { Easting } \\
(\text { dd.ddd })\end{array}$ & $\begin{array}{l}\text { Northing } \\
\text { (dd.ddd) }\end{array}$ & $\begin{array}{r}\text { Elevation } \\
\text { (m a.s.1.) }\end{array}$ & $\begin{array}{r}\text { Installed } \\
(\mathrm{MM} / \mathrm{YY})\end{array}$ & $\begin{array}{r}\text { Installed depth } \\
(\mathrm{m} \text { b.g.s. })\end{array}$ & $\begin{array}{l}\text { Measured depth } \\
\text { to water (m b.g.s.) }\end{array}$ & $\begin{array}{l}\text { Measured depth } \\
\text { to bottom (m b.g.s.) }\end{array}$ \\
\hline BH1 & 42.049950 & 42.781550 & 566.6 & $07 / 15$ & 45 & 7.4 & 35 \\
\hline $\mathrm{BH} 2$ & 42.050650 & 42.782500 & 568.2 & $07 / 15$ & 50 & 1.5 & 36 \\
\hline $\mathrm{BH} 3$ & 42.049850 & 42.784583 & 587 & $07 / 15$ & 32 & 1.3 & 16 \\
\hline BH4 & 42.050583 & 42.784417 & 652.8 & $07 / 15$ & 65 & 1.3 & 16 \\
\hline BH5 & 42.052633 & 42.787150 & 679.7 & $07 / 15$ & 50 & 0.0 & 42 \\
\hline BH5 & 42.052633 & 42.787150 & 679.7 & $07 / 15$ & 50 & 0.5 & 42 \\
\hline BH6 & 42.053017 & 42.779717 & 725.9 & $07 / 15$ & 50 & 12.0 & 18 \\
\hline BH7 & 42.055433 & 42.781700 & 721.3 & $07 / 15$ & 50 & 5.8 & 49 \\
\hline BH8 & 42.055883 & 42.786517 & 704 & $07 / 15$ & 55 & 4.8 & 23 \\
\hline BH9 & 42.051800 & 42.788767 & 702.6 & $07 / 15$ & 51 & -0.2 & 37 \\
\hline BH10 & 42.051800 & 42.790167 & 727.9 & $07 / 15$ & 50 & Broken & Broken \\
\hline
\end{tabular}
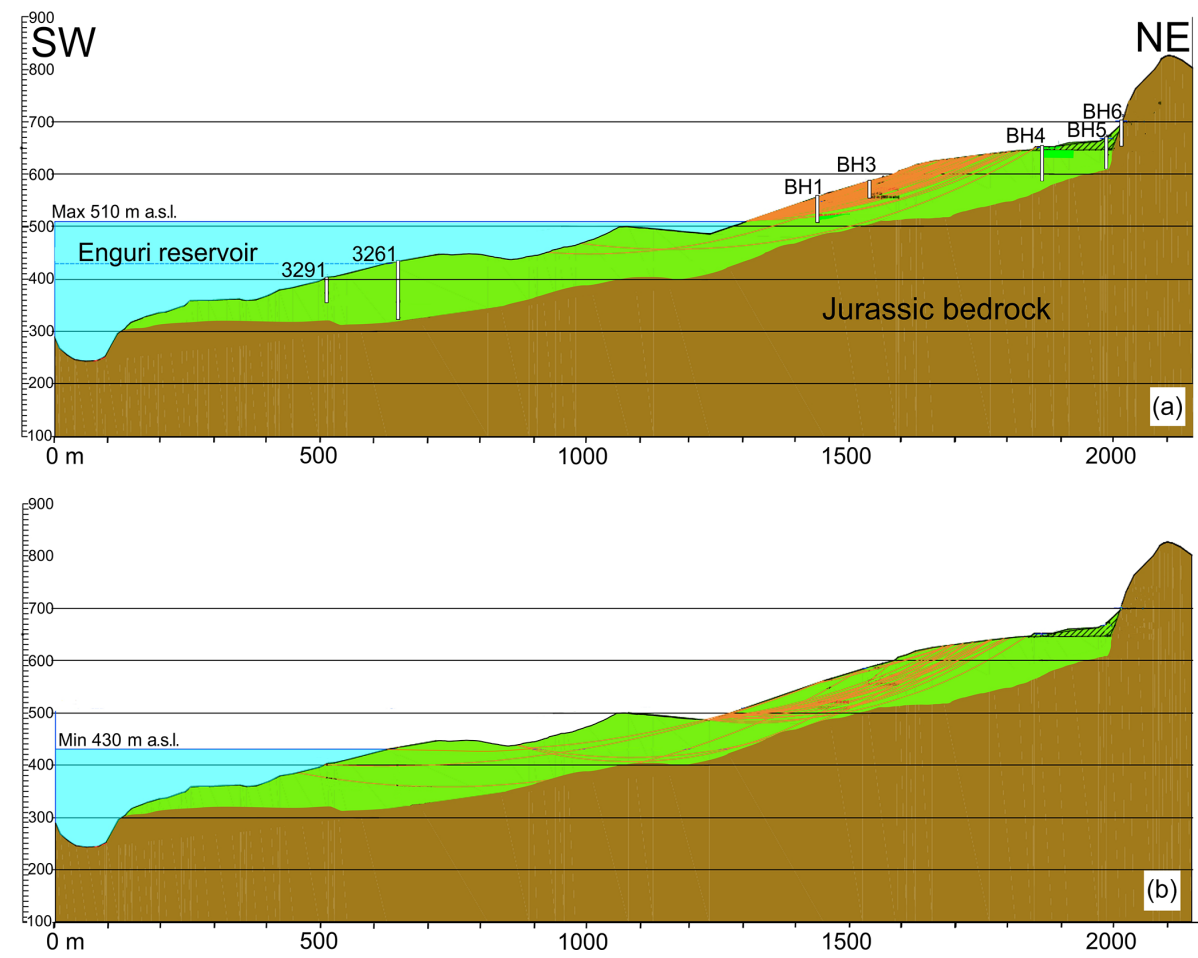

Figure 11. Sections of the static analysis developed to assess the effect of variation of the water level in the main landslide body. (a) Instability developed with a maximum level of the reservoir water (orange lines show the slip surfaces with FS $<1$ ). (b) Analysis of the effect of variation of the reservoir water level down to the minimum level; note new slip surface (with FS < 1) formation at lower elevations.

during the rainy season. The model indicates that upper parts of the slope are unstable along curvilinear slip surfaces (orange lines) that correspond to the factor of safety (FS) $<1$. Most slip surfaces are shallow (10-30 m) and affect limited parts of the onshore slope.

In the second static model, the reservoir water level has been considered at a minimum (430 ma.s.1.), resulting in more diffuse instability of the slope, including the part normally below the lake. The relative slip surfaces (orange in
Fig. 11b) correspond to FS $<1$, and are mostly deeper (30$80 \mathrm{~m}$ ) than in the previous case.

The pseudostatic numerical model was developed using a peak ground acceleration (PGA) that has been selected according to the procedure briefly outlined here below. Since local strong motion records for Georgia do not exist, we selected the seismograph record of the northwestern Balkan Peninsula earthquake (epicentral distance $19.7 \mathrm{~km}$; depth $3.75 \mathrm{~km} ; M_{\mathrm{W}}=6.9$; site class B; 15 April 1979, 06:19:41; lat $42.04^{\circ}$, long. $19.05^{\circ}$ ) (Fig. 12). We have chosen this record 


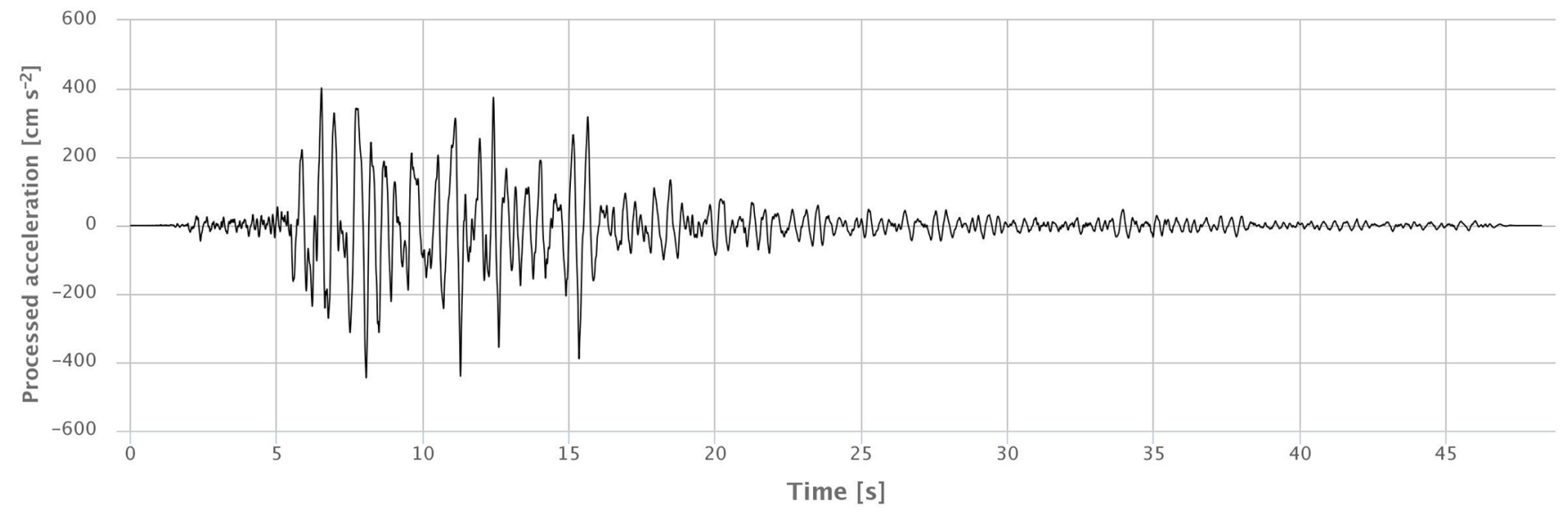

Figure 12. Seismic acceleration record used for the pseudostatic and Newmark slope stability analysis. See text for details.

Table 3. Calculated values of PSH.

\begin{tabular}{lrrrrr}
\hline Vs30 30 & PSH 10\% & PSH 5\% & PSH 2\% & PSH 1\% & DH_0.5 \\
\hline 497 & 0.45 & 0.56 & 0.75 & 0.91 & 0.65 \\
548 & 0.44 & 0.56 & 0.74 & 0.9 & 0.65 \\
576 & 0.43 & 0.56 & 0.74 & 0.88 & 0.65 \\
760 & 0.4 & 0.51 & 0.68 & 0.82 & 0.6 \\
\hline
\end{tabular}

from ESM (Engineering Strong-Motion database; http://esm. mi.ingv.it/, last access: 20 May 2018) due to the very similar seismotectonic conditions with respect to the Enguri site and the fact that it is based on probabilistic seismic hazard assessment (PSHA). PSHA was done according to international standards (Sesetyan et al., 2018) based on the reliable catalogue of earthquakes of the region and on the catalogue of active faults of Georgia that provides information on their dimension, strike, dip, kinematics, $M_{\mathrm{w}}$ max and slip rate, as well as area seismic source zone models (Danciu et al., 2018). The ground motion prediction equation model was established for shallow active crustal regions following the criteria by Cotton et al. (2006). For site investigation (estimate Vs30 - average shear velocity for $30 \mathrm{~m}$ depth; Table 3), we assessed the geophysical characteristics of the deposits affected by the landslide based on the available borehole data and new measurements using MASW (multichannel analysis of surface waves) and HVSR (horizontal to vertical spectral ratio) methods. The MASW approach allowed us to assess the relative shear strength of subsurface deposits, which, integrated with density values of the local bedrock and overburden sediments (obtained by the logs), resulted in shear modulus (dynamic ground stiffness). We used vertical geophones with 24 channels and $4.5 \mathrm{~Hz}$. The HVSR was based on ambient seismic noise registration as a single measurement, a method widely used for the site investigation studies in the last 2 decades (Bard, 1999; Bonnefoy-Claudet, 2006). It provides important information on the vertical distribution of $P$ and $S$ seismic wave velocities. In particular, in order to evaluate the $S$-wave velocity profile with depth, we used the joint inversion of the Rayleigh wave dispersion curve and the $H / V$ curve. This inversion procedure was carried out by a multimodal Monte Carlo inversion based on a modified misfit function (Maraschini and Foti, 2010). We used a Tromino seismometer installed very close to boreholes to compare HVSR curves with local geology and to validate results. Seismic noise was recorded for $60 \mathrm{~min}$ at each site, for a total of 13 sites. Measurements were carried out during the night or very early morning to avoid any artificial transients. In this way, velocity profiles and Vs3030 values were estimated. As an example, the Vp and Vs30 velocity profiles are shown in Fig. 13, for which it is possible to appreciate a series of discontinuities that in most cases correspond to the interface with the substratum, or are within the Quaternary deposits. In the uppermost part of the landslide, along the Jvari-Mestia road, the joint inversion analysis shows relevant resonance interfaces that vary from 14 to $21 \mathrm{~m}$ (from measurement point MST_6 to TR_1 along the road), corresponding to an increase of S-wave velocity from 936 to $985 \mathrm{~m} \mathrm{~s}^{-1}$. Comparison with $\log$ data indicates that this is a discontinuity within the brecciated deposits. The profiles also show another S-wave velocity increase at 51.6m (MST_9) and $53.6 \mathrm{~m}$ (TR_1), corresponding to variation from 1025 to $1130 \mathrm{~m} \mathrm{~s}^{-1}$. This might correspond to the interface with the more intact substratum. These measurements, and others corresponding to the lower part of the slope, suggest a geometry of the deposits and rocks corresponding to the geological and geotechnical sections of Figs. 8, 11 and 14.

In a further step, we prepared a digital elevation model (DEM) of the slope using topographic maps at a $1: 2500$ scale. The DEM was converted to a slope map and the correlation between the slope and Vs30 30 was adopted for the whole area of the landslide. Finally, taking into account the inputs of source models (the active fault source model and the area source models) and the ground motion prediction equation models, we performed a probabilistic seismic 


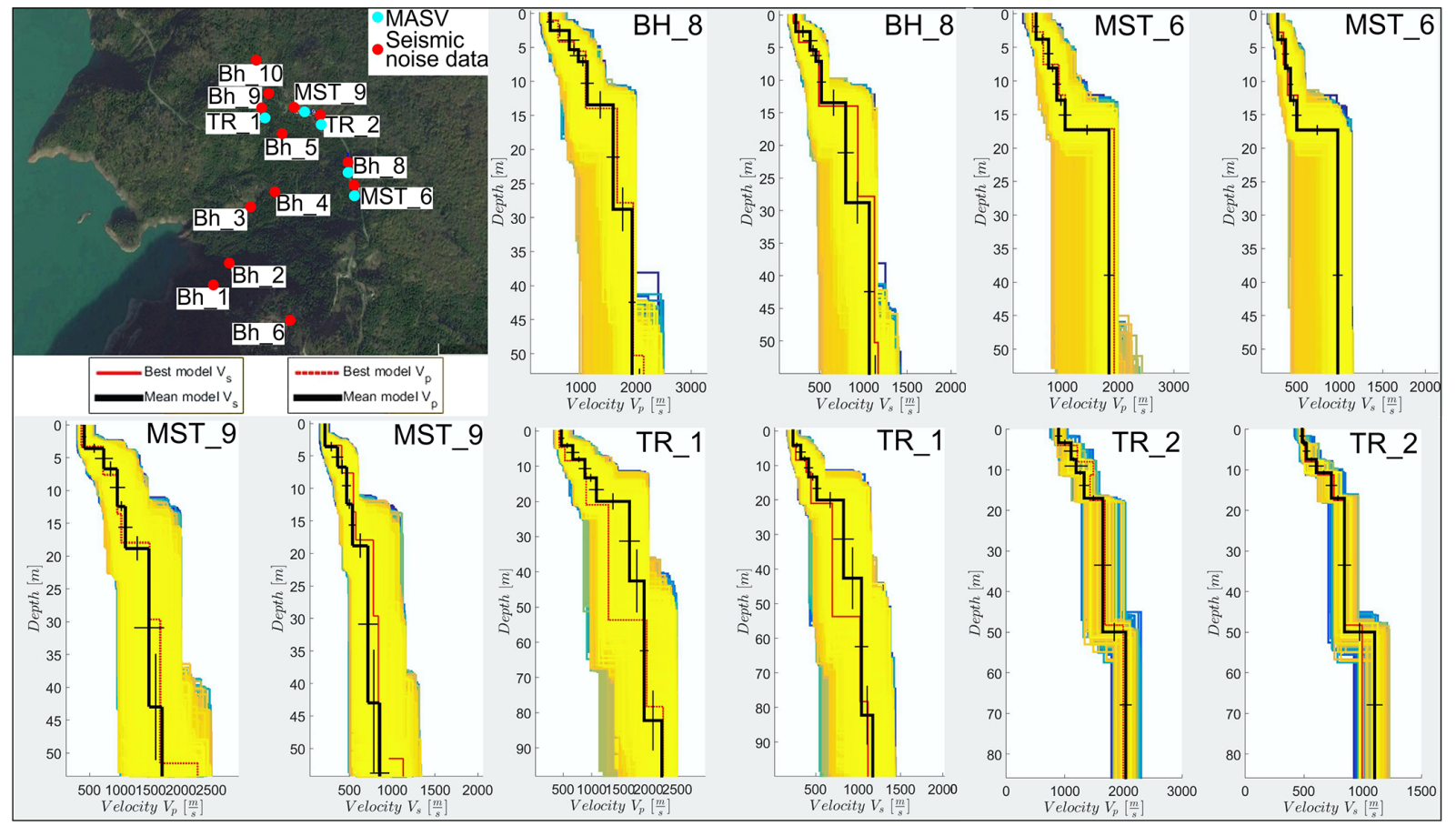

Figure 13. Examples of some of the Vp and Vs30 velocity profiles measured along the slope affected by the western landslide. All sites of MASW and seismic noise measurement are shown in the inset.

hazard (PSH) assessment in order to individuate the characteristic earthquakes for PGA calculation. PSH was calculated for each point taking into account the site characteristic Vs30 for a probability of exceedance of $10 \%, 5 \%, 2 \%$ and $1 \%$ in 50 years (Table 3 ). We used the EZFRISK software for earthquake ground motion estimation. Results show that the expected possible scenario is represented by a PGA of $0.46 \mathrm{~g}$ for site class B. Finally, the PGA was multiplied by a reference acceleration coefficient of 0.17 (Kavazanjian et al., 1997) to obtain a seismic load coefficient of 0.07 $(\mathrm{kh}=\mathrm{PGA} \times 0.17)$.

The pseudostatic analysis is presented in Fig. 14a, with the orange and red slip surfaces corresponding to $\mathrm{FS}<1$. Comparing the static (Fig. 11a) and pseudostatic analysis (Fig. 14a), it is evident that the susceptible slip surfaces are not just restricted to the upper part of the slope but extend all along the Quaternary deposits due to seismic shaking, and are deeper since they reach the interface with the substratum. The full dynamic modeling of the slope to estimate the displacements expected from seismic shaking along the slope was done using the Newmark approach. The tolerable displacement is about $1 \mathrm{~m}$ (Kavazanjian et al., 1997) and any displacement $>1 \mathrm{~m}$ could lead to failure. It is evident from Newmark analysis (Fig. 14b - red slip circles represent failure surfaces that would experience displacements $>1 \mathrm{~m}$ ) that the whole slope, down to the presently submerged slope toe and even parts of the bedrock, could experience displacements $>1 \mathrm{~m}$. The estimated displacements indicate that the slope is highly susceptible to seismic triggering and could lead to failure of the slope into the reservoir in the event of seismic activity compatible with or greater than the PGA here calculated.

\subsection{Monitoring active deformation}

Due to the evidence of active slope deformation, we installed two digital extensometers (Wire Linear Potentiometric Transducer, SF500) that record the deformation across the upper scarp of the western landslide continuously. One extensometer was installed on 1 November 2016, and the other one a few months later. In Fig. 15 we show the data collected at the older instrument (location at Trench 2; Fig. 7a), together with data regarding lake level variation, amount of rain and internal and external (wire) temperatures, from 1 November 2016 to 15 May 2018. The total amount of deformation here is $67 \mathrm{~mm}$ in 18.5 months, which gives an average extension rate of $4.3 \mathrm{~cm} \mathrm{yr}^{-1}$. Deformation largely increased from 16 May to 8 August 2017 with a total extension of $52 \mathrm{~mm}$ that corresponds to a rate of $0.61 \mathrm{~mm} \mathrm{day}^{-1}$ (as a comparison, the average extension rate is $0.13 \mathrm{~mm} \mathrm{day}^{-1}$ for the whole period of measurement). This interval of extension rate increase follows the almost complete drawdown of the lake (21 February 2017) and the successive period of lake level infilling, although a delay of about 1 month can be recognized. Another interval of rate increase, although much smoother than the previous one, is recognizable after 6 March 2018, in concomitance with another increase in lake level. During periods 


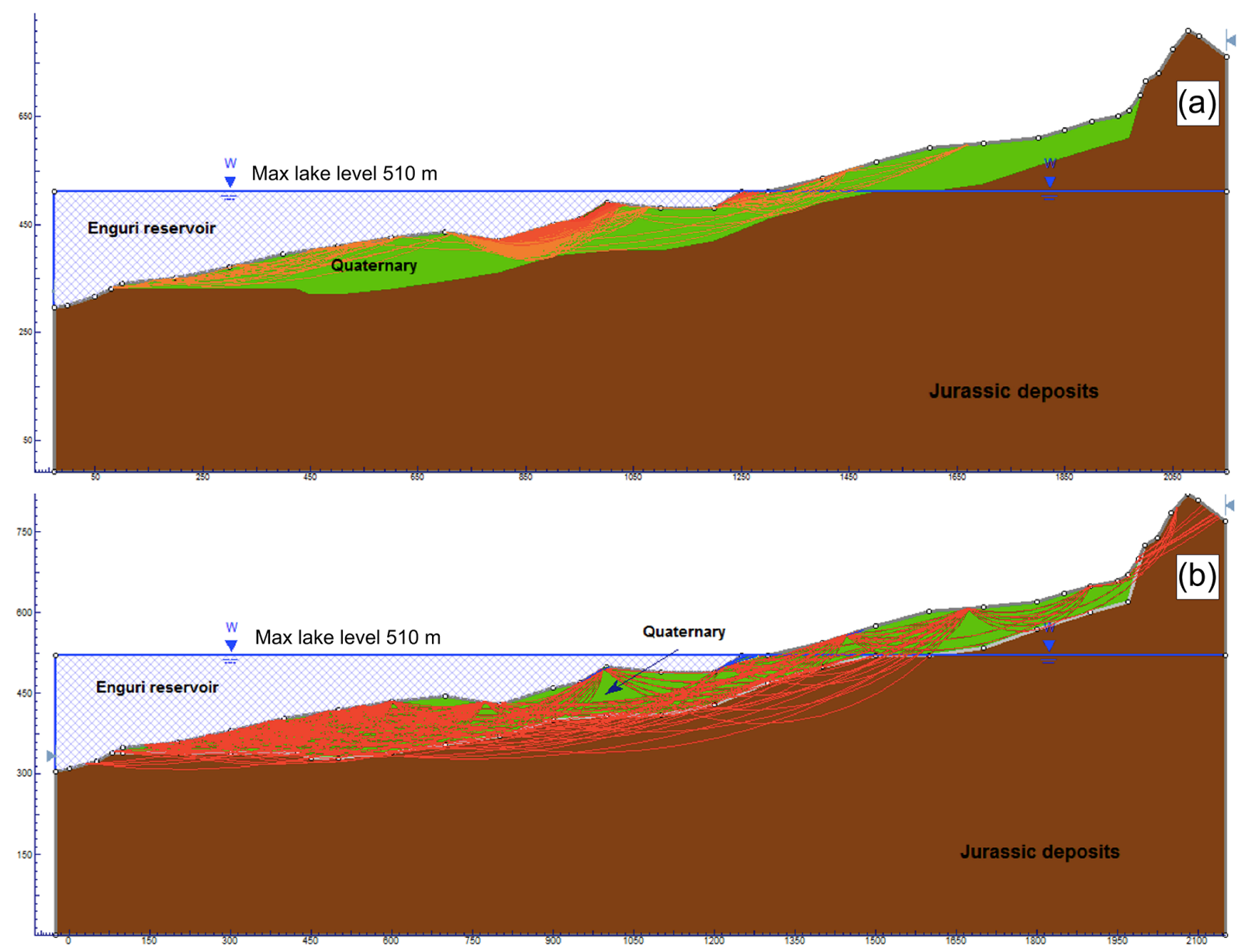

Figure 14. Results from seismic slope stability analysis. (a) Pseudostatic analysis showing the development of several potential slip surfaces (orange and red lines) with FS $<1$. (b) Dynamic modeling, using a Newmark approach, showing the development of several large slip surfaces (red lines) that would experience more than $1 \mathrm{~m}$ of displacement. Since $1 \mathrm{~m}$ is considered a critical displacement that would yield failure, these slip surfaces indicate very unstable conditions along the slope in case of an earthquake producing the calculated local seismic shaking.

of lake level lowering, the extension here tends to decrease to minimum values. The amount of rain and temperature variations do not seem to affect the extension values.

\section{Discussion}

\subsection{Evidence of active landslides}

In the study area, we found much evidence of active slope deformation that affects the same mountain ridge on both the western and eastern flanks. Although part of the western landslide was already locally known as Khoko, this is the first time that its characteristics are reported in the scientific literature, whereas the eastern landslide has never been recognized before. For example, in the Geoportal of Natural Hazards and Risks in Georgia (http://drm.cenn.org, last access: 15 April 2018), in the section dedicated to landslide hazard, the map reports a medium landslide hazard at all the slopes located east of the Enguri reservoir without distinction, in correspondence with the large, active structures presented in our paper.

Regarding the western landslide, the data presented here allowed us to define its real total dimension, suggesting that the unstable slope area is larger than the previously known Khoko landslide. We recognized the presence of a main head scarp that runs upward in respect to the Jvari-KhaishiMestia road (i.e., east of the road; Fig. 6a) in the northerncentral part, then crosses the road and runs west of it. This scarp is made up of three main segments, with the concave side (in plan view) facing west. The segments are interconnected, and thus the total head scarp is continuous, suggesting that the process of slope instability has already led to the linking together of what originally might have been a series of discrete landslides. Historical and present-day activity along this landslide is manifested by the presence of fissures and slip planes at the foot of the head scarp, subsidiary 


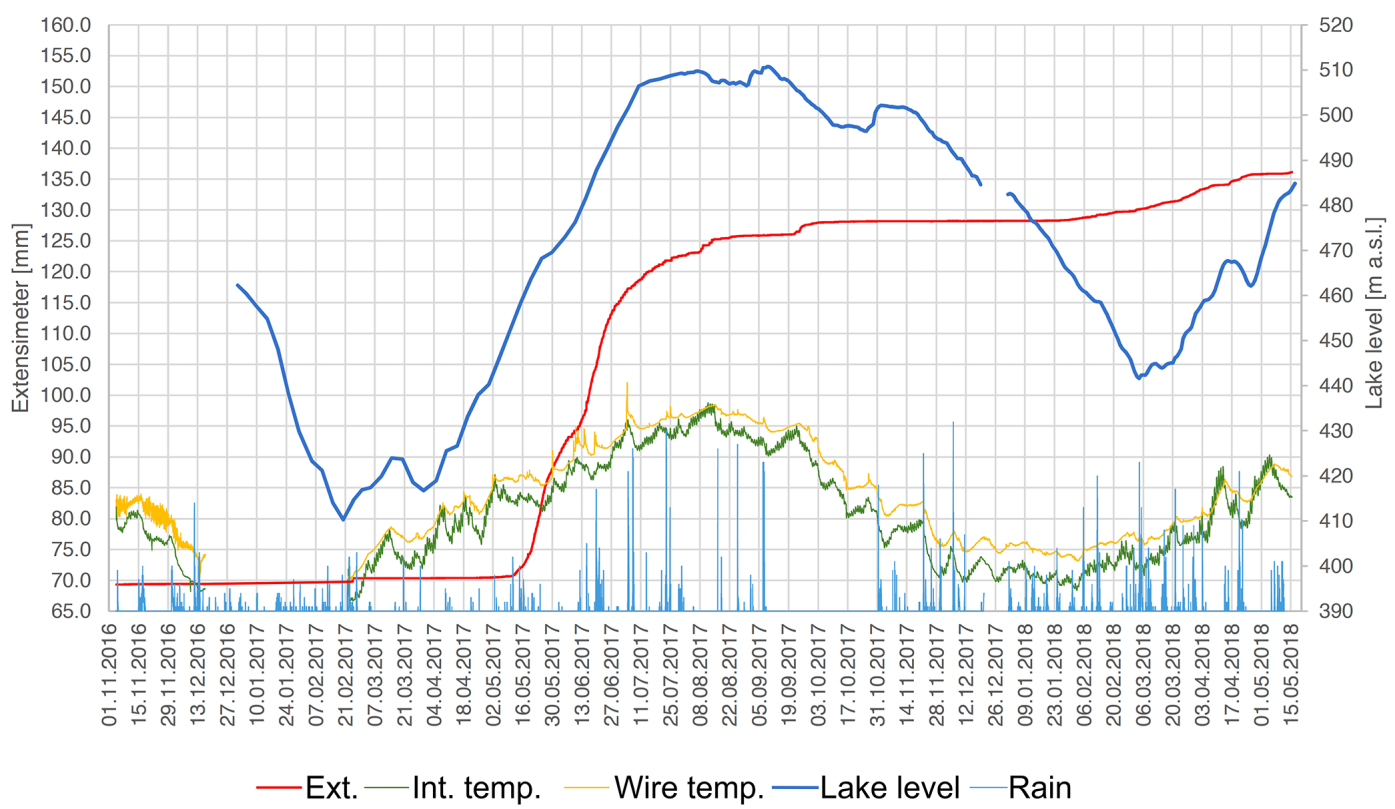

Figure 15. Data acquired from one of the two digital extensometers located at the upper scarp of the western landslide (location Trench 2; Fig. 7a). The blue line shows the lake level, the red line the extension, the yellow line the external (wire) temperature, the green line the internal temperature and the light blue lines the amount of rain.

scarps in the slope and systematic tilted trees all along the slope. Where the Jvari-Khaishi-Mestia road crosses the active structures, it requires continuous maintenance in order to fill the opening fractures and smooth the scarps created along the slip planes.

The eastern landslide shows the main head scarp that runs upward respect to the Jvari-Khaishi-Mestia road (i.e., west of the road; Fig. 10). It is made of a single structure with the concave side (in plan view) facing east. Historical and present-day activity along this landslide is manifested by the presence of fissures along the head scarp, some of which are located in the forest and some of which cross the JvariKhaishi-Mestia road that also requires continuous maintenance. Moreover, the $1.9 \mathrm{~m}$ left-lateral strike-slip offset of the old concrete wall is compatible with landslide movement along the lateral slip plane.

\subsection{An old history of slope deformation}

We found evidence that the studied western slope has a long history of landslides. The geological map surveyed during Soviet times, before the infilling of the water reservoir, shows the presence of prehistoric landslide deposits, with a thickness of up to 35-40 m, at the lower part of the slope, now submerged (see Fig. 4 and section in Fig. 8b). Moreover, at the foot of the present onshore slope, there are gypsum deposits that are extremely deformed; this might result from a long history of tectonic movements or from localized landslide movement, or from a combination of both. Whatever the origin, the presence of gypsum deposits favors slope in- stability. There is also much evidence suggesting that both the western and eastern landslides started their movement at least several decades ago. The western landslide was already moving during the construction of the pavement of the old Jvari-Khaishi-Mestia road. This road was improved during the construction of the Enguri dam, in the Soviet era, by laying a very thick concrete flooring, as showed in Trench 1, which we opened across one of the active slip planes located at the foot of the head scarp (Fig. 7c). The thickness of this concrete layer of $0.5 \mathrm{~m}$ and its presence suggest that it was required possibly due to the recognition at that time of active deformation along this road segment. In fact, during the Soviet era, the general thickness of concrete roads was much less. Moreover, the lowered concrete pavement $(1.3 \mathrm{~m})$ with respect to the present road level confirms an ongoing process of subsidence here. Then it was followed by the construction of a further road, found $20 \mathrm{~cm}$ below the present road level in Trench 1 and 2, which also confirms continuous downsagging of the area. Here, the present-day road surface suffers continuous offsetting, with a consequent necessity to accumulate further tens of centimeters of asphalt to maintain the road level.

The eastern landslide also has evidence of an old history; the small lake at the foot of the head scarp is interpreted here as being a result of upward tilting of the uppermost part of the landslide body. The thick clay deposits associated with this lake suggest that it is relatively old. The dimension of the trees grown within the fissures located uphill of the head scarp also suggests that these fissures opened at least some decades ago. Moreover, several man-made structures show 
incremental offset with age (the concrete wall of the 1970s, the water channel, the white strips of the asphalt, etc.), confirming the gradual continuous movements of this landslide.

\subsection{Kinematics}

The height of the head scarp of the western landslide (20$70 \mathrm{~m}$ ) indicates that there was an important vertical slip in the head zone. The presence of a wide subhorizontal to gentle slope at the scarp foot, which has been exploited for the construction of the Jvari-Khaishi-Mestia road, associated with the presence of the head scarp, suggests the development of rotational movements of the upper slope. Ongoing development of vertical scarps in the asphalt of the road and the presence of gentle scarps in the middle slope indicate that rotation movements are still present in different zones of the landslide area. The orientation of the active fissures and slip planes surveyed on the road, which are parallel to subparallel to the main head scarp, and the presence of dip slips along the vertical scarps, indicate a general movement of this western landslide towards the west. In detail, the movement is more complex since the northern part shows motions towards SSW, the central part toward W and the southern part toward NW. These vectors, together with the general shape of the landslide in plan view, suggest that there is a concentric movement of the landslide body towards the toe zone, where bulging and decrease of motion are expected. Since the tow zone is under the Enguri lake, it is impossible to verify what occurs in the lowermost part of the landslide.

In regard to the eastern landslide, in the field there is clear indication of several meters of vertical slip along the head scarp, at the foot of which there is a flat area that contains the small lake. A portion of this subhorizontal area has also been exploited here to host the Jvari-Khaishi-Mestia road. These data indicate the presence of rotational movements of the upper slope. The northern lateral boundary of the landslide is characterized by a prolongation of the main head scarp that crosses the road. At this point, the concrete wall built in 1974 CE shows tilting northward, compatible with the downthrow of the southern block. The same wall also shows the 1.9 left-lateral strike-slip offset that is compatible with the general eastward motion of the landslide body. The northern boundary of the landslide is thus characterized by transtensional movements that also comply with rotational deformation of the upper part of the unstable slope.

\subsection{Slip rates}

For the western landslide, Trench 1 allows us to estimate a long-term (57 years) slip rate of the vertical component of motion on the order of $2.3 \mathrm{~cm} \mathrm{yr}^{-1}$, based on the age of the oldest buried road built about $1960 \mathrm{CE}$. Our repeated observations on the development of fissures and vertical scarps onto the asphalt of the modern road surface, conducted in the years 2015-2017, indicate slip rates from $<1$ up to
$9 \mathrm{~cm} \mathrm{yr}^{-1}$, depending on the location of the examined structure. We remind the reader that these features are usually destroyed during restoration of the asphalt pavement. The data of the installed extensometer indicate an extension rate of $4.3 \mathrm{~cm} \mathrm{yr}^{-1}$ in the last 1.5 years. In general, it seems that the slip rate increases from south to north along the upper part of the landslide, although this observation requires detailed measurements to be confirmed. For this reason, we installed a network of 18 benchmarks distributed all along the upper part of the landslide. GPS measurements started in late 2016 and will be published in a future paper.

For the eastern landslide, the $190 \mathrm{~cm}$ offset of the concrete wall (November 2015) and its age which dates back to $1974 \mathrm{CE}$ result in a slip rate of $4.6 \mathrm{~cm} \mathrm{yr}^{-1}$ for the long-term (41 years) motion towards east. The offset measurement in May 2017 of the same wall results in a short-term slip rate of $3.75 \mathrm{~cm} \mathrm{yr}^{-1}$. The water channel offset was measured between November 2015 and May 2017, giving a short-term slip rate of $1.5 \mathrm{~cm} \mathrm{yr}^{-1}$. The overall offset and the age of the white strips on the road give an estimation of $4 \mathrm{~cm} \mathrm{yr}^{-1}$ for the short-term slip rate ( 2 years). We remind the reader that the road deformation features are also destroyed here during periodic restoration of the asphalt pavement.

\subsection{Possible origin of slope deformation}

As regards the dimension and type of the western landslide, for which more data are available, it is necessary to stress that this slope is characterized by the presence of a thick shallow succession of debris and clay-gypsum deposits on the order of at least $30-80 \mathrm{~m}$. This indicates the presence of a thick sequence of deposits that have poor mechanical properties and that are widespread all over the investigated slope. In fact, both static and dynamic analyses indicate the possible development of several slip planes (characterized by $\mathrm{FS}<1$ ). In particular, the dynamic modeling shows slip surfaces with FS $<1$ that reach depths on the order of $80-100 \mathrm{~m}$. In the field, there is clear evidence of rotational deformation in the upper part of the unstable slope, accompanied by dip slips along the planes perpendicular to the general downhill motion. These data do not fit with the interpretation of slope deformation linked to scattered, discrete surficial small landslides, but are instead consistent with a slope affected by a unique landslide. Based on numerical simulations, the depth of the possible slip surfaces that might develop especially under earthquake solicitation indicates a probable DSGSD.

The similar position and features of the western and eastern landslides cannot be a mere series of coincidences, and we cannot exclude the possibility that they have a common origin. The toes of the two unstable slopes are located at 400 $300 \mathrm{~m}$ a.s.l., which corresponds to the level of erosion of the present river located at the foot of the eastern landslide, and to the original river level at the base of the western landslide, now hidden below the Enguri water reservoir. The two river valleys have a $V$ geometry in section view and affect areas 
mostly at altitudes lower than $1900 \mathrm{~m}$ a.s.l., which represents the lower threshold of former glaciers of the Last Glacial Maximum (LGM) phase (late Pleistocene) defining the lower boundary of the nival zone (Gobejishvili et al., 2011). This means that the two river valleys might have started to form before the LGM, but they fully developed down to the present depth in consequence of the post-LGM water runoff. Both valleys reach the common flood plain of the Rioni Basin at the same altitude. All these features suggest that the two river valleys developed at the same time, contributing to create the topographic gradient at the two sides of the mountain ridge. Based on all this information, we suggest that the triggering factor in the development of the two landslides might have been the increase above a threshold value of the slope dip and of the topographic altitude difference created by river erosion.

The above-mentioned valleys have been deeply incised by river activity, consistent with the recent mountain uplift of the region. Thus, the formation of the two river valleys and the consequent development of the mountain ridge that gave rise to the two landslides may also be linked with tectonic uplift. An increase in Plio-Pleistocene exhumation rates in northwest Georgia is supported by thermochronometric studies (Vincent et al., 2011) that show that the southern flank of the western Greater Caucasus range has undergone rapid exhumation of $\sim 1 \mathrm{~km} \mathrm{Ma}^{-1}$ from the Pliocene onwards. In particular, the geological structural setting of the study area is characterized by the presence of thickening of the shallow crustal succession caused by thin-skin tectonics, as introduced in Fig. 2. Although the crustal section of Fig. 2 is at a much broader scale than the area studied here, it allows us to recognize that the landslides developed in a part of the mountain belt that was subject to enhanced uplift in correspondence with the ramp anticline. Under this structural architecture, and taking into account the seismic activity of the western Caucasus (Tsereteli et al., 2016), an earthquake with the consequent ground acceleration, cannot be ruled out as a possible trigger for one of the two landslides or for both. Landslides aligned along active faults and triggered by seismic activity have been observed frequently elsewhere (e.g., Tibaldi et al., 1995, 2015). The available seismic catalogue in the area goes back to the Tsaishi earthquake that occurred in 1614 CE (Tibaldi et al., 2017b), and thus does not allow to establish a possible direct relationship, also in view of the fact that the exact age of inception of these landslides is unknown.

A gross estimation of the possible age of the studied landslides can be done if we assume a constant deformation rate; for the western landslide, with the average height of the head scarp $(45 \mathrm{~m})$ and average slip rate $\left(3 \mathrm{~cm} \mathrm{yr}^{-1}\right)$, we obtain a rough age of the landslide on the order of 1500 years. For the eastern landslide, the average height of the head scarp $(30 \mathrm{~m})$ and average slip rate $\left(3.5 \mathrm{~cm} \mathrm{yr}^{-1}\right)$ give a gross age estimation on the order of 900 years.

\subsection{Hydrogeological hazard}

Although this is a preliminary description of the evidence and characteristics of the landslides located near the Enguri dam, the data presented here are enough to pinpoint a series of relevant results on the hydrogeological hazard of the area. First of all, the western landslide faces the Enguri reservoir directly, with the toe zone of the unstable slope located below the water level, as shown by the pseudostatic and dynamic analyses that are justified by the fact that the studied area is located in an active tectonic region where earthquakes with $M_{\mathrm{S}}$ up to 7.0 have been recorded (Varazanashvili et al., 2011). This slope moves continuously in a sort of creeping movement, as already observed elsewhere in DSGSDs (Varnes et al., 1989, 1990, 2000). It has also been observed that movements in DSGSDs can be intermittent (Beget, 1985); they can slow down or stop, and then suddenly reactivate with rapid downward displacement also on the order of meters, without a complete failure (Tibaldi et al., 2004; Tibaldi and Pasquaré, 2008; Pasquaré Mariotto and Tibaldi, 2016). Anyway, the occurrence of a sudden downhill displacement of the western landslide, for example during seismic shaking as indicated by the Newmark analysis, can involve a huge rock volume, on the order of $48 \pm 12 \times 10^{6} \mathrm{~m}^{3}$. This might have an effect on the water body, and this hypothesis is worth further studies on the topic.

Our preliminary static analysis suggests that slope movements can occur both when the lake is at the highest level and when it is lowered. This result does not necessarily suggest a possible catastrophic failure of the slope in static conditions, but is instead coherent with the field evidence of continuous deformation along the slope. We interpret this as a consequence of the characteristics of the deposits along the slope. Slip surfaces can activate especially in the part of the slope above the lake level because here deposits rich in clays, and very altered tuffs, dominate. When the water table lowers from 510 to $430 \mathrm{~m}$, although a rapid drawdown condition is created, the shallow deposits of the upper slope remain saturated due to their low hydraulic conductivity. Moreover, an increase of movements can occur during phases of saturation of the onshore landslide body that may take place particularly during the rainy season. At the lowest lake level, slip surfaces can activate in the lower part of the slope due to debuttressing of the slope toe, although deposits with a relatively high hydraulic conductivity dominate here.

The two studied landslides also pose a threat to other infrastructures like the Jvari-Khaishi-Mestia road, which in fact requires continuous maintenance to avoid the gradual formation of dangerous steps in the asphalt that are tens of decimeters high. We also highlight the presence of an inhabited house resting in the middle of the western landslide, and another house recently built close to the northern boundary slip zone of the eastern landslide.

In order to contribute to a better assessment of the hydrogeological hazard of the area, we installed two digital exten- 
someters in correspondence with the active head structures of the western landslide, together with the benchmarks for GPS measurements that have already been mentioned. This monitoring effort will help to individuate possible alert situations and to better constrain the behavior of this unstable slope.

\subsection{Comparison with other landslides}

Here we focus on the western landslide, its relations with the artificial lake and similar settings reported by literature. As shown by the Quaternary geological deposits and by the presence of the high head scarp, the studied area was already affected by the emplacement of landslide deposits in prehistoric times. The already destabilized slope was thus interested by the formation of the Enguri reservoir and its level variations. The creation of artificial lakes can have different effects: on one side, it triggers a possible seepage process, resulting in an increase in porewater pressure within the slope deposits, thus reducing their shear strength. On the other side, the presence of the lake water body induces a stabilizing load at the toe of the submerged part of the slope (Paronuzzi et al., 2013). In transient conditions, the rate of lake filling or drawdown, combined with the permeability of the bank-forming materials, produce different effects of reservoir level changes. Several landslides, in fact, have been triggered by filling-drawdown operations (Schuster, 1979; Kenney, 1992; Zhu et al., 2011); pre-existing, ancient landslides have been reactivated during water reservoir formation as well (e.g., Kaczmarek et al., 2015).

In the case of low permeability of slope materials, rapid drawdown of the lake level can produce a decrease in the factor of safety, possibly leading to slope failure (Kenney, 1992). A rapid decrease in lake level, in fact, results in a short-term increase in hydraulic gradient in adjacent slopes (Jones et al., 1961; Schuster and Wieczorek, 2002; Deying et al., 2010; Pinyol et al., 2012). For example, in Japan about $60 \%$ of reservoir landslides occurred during a sudden decrease of the water level (Nakamura, 1990). In a DSGSD located above the Gepatsch Dam reservoir (Austrian Alps), slope deformation rates correlate with reservoir levels and drawdown conditions (Zangerl et al., 2010). In the case, instead, of high permeability of bank-forming materials, the reservoir level increase can produce a decrease in the factor of safety. For example, for the Vajont (Italy) catastrophic landslide, detailed numerical analyses by Paronuzzi et al. (2013) show the predominant role played by reservoir levels in determining slope instability, with respect to the rain-induced water table in the upper slope. In particular, the initial large slope deformation took place in concomitance with the lake level rise. Consistent with this trend, the final collapse of 9 October 1963 coincided with the maximum reservoir level being reached. Paronuzzi et al. (2013) also show that the decisive geological factor contributing to the Vajont collapse was the presence of a landslide that already existed: the prehistoric rockslide was characterized by materials with high permeability and a thick shear zone at the base, including montmorillonitic clay lenses. The combination of poor mechanical properties of clay beds with the high permeability of the angular limestone gravel determined a rapid reservoir-induced inflow that reduced strength and the factor of safety. A further example is given by the Byford Creek slide, located above the Clyde Dam reservoir (New Zealand). Here, long-term creep movements show a clear reaction to lake filling, with an initial large increase in the deformation rate and long-term slowing of movement (Macfarlane, 2009).

The landslide studied here, more than 40 years since the construction of the Enguri reservoir, still shows a high sensitivity to water infilling operations. The unstable slope behavior, during large water level variations, is similar to other landslides with bank-slope material characterized by high permeability. In particular, the deposits found in the logs of the lower part of the slope (below about $500 \mathrm{~m}$ a.s.l.), being characterized by the dominance of angular carbonatic clasts with interspersed clays, are similar to those present at other landslides, for which the factor of safety decreases with increase of lake level. With such characteristics of the materials affected, during reservoir increase the porewater pressure effect on the shear strength prevails over the stabilizing buttressing of the lake water body, inducing an acceleration in slope movements. This is evidenced by the acceleration in slope deformation following the Enguri reservoir infilling (Fig. 15).

\section{Conclusions}

We presented, for the first time, the evidence and characteristics of two large landslides located near the Enguri dam and water reservoir, in the southwestern part of the Caucasus (Republic of Georgia).

The landslides affect the two opposite slopes of a mountain ridge that runs parallel to the Enguri reservoir. The slope directly facing the reservoir shows active deformations that involve a subaerial area of $1.2 \mathrm{~km}^{2}$. Field data, information from wells, seismological data including calculation of the local peak ground acceleration (PGA) and slope stability analyses indicate different depths of the possible sliding surfaces, depending on various parameters. The worst scenario is given by the occurrence of a PGA compatible with the highest seismicity of the region, which can contribute to activate slip surfaces at depths corresponding to a volume of the unstable mass of up to $48 \pm 12 \times 10^{6} \mathrm{~m}^{3}$.

The head scarp zones of both landslides affect the main Jvari-Khaishi-Mestia road with offsets of man-made features that indicate short-term (last 2 years) slip rates of up to $9.3 \mathrm{~cm} \mathrm{yr}^{-1}$ and long-term (last 55 years) slip rates of up to $4.6 \mathrm{~cm} \mathrm{yr}^{-1}$.

The possible causes for the past inception of the two landslides are multiple. First of all, we propose the increase above a threshold value of the slope dip and of the topographic al- 
titude difference created by river erosion. The toe zones of both landslides, in fact, are located in correspondence with deeply entrenched rivers; the river's location at the foot of the western landslide is now below the Enguri water reservoir. The excavation of the two parallel river valleys, in turn, can be linked with the increase in Plio-Pleistocene exhumation rates of this mountain area of $\sim 1 \mathrm{~km} \mathrm{Ma}^{-1}$. The study area, in particular, is located above an anticlinal fold linked with a ramp thrust fault. A tectonic seismic mechanism, with the consequent ground acceleration, cannot be ruled out as a possible trigger for one of the two landslides or for both.

Extensometer measurements across the head scarp of the western landslide indicate a present-day variable deformation (average $4.3 \mathrm{~cm} \mathrm{yr}^{-1}$ ). The deformation rate variations are poorly consistent with rain amount, whereas extensometer data suggest that the landslide body is more sensitive to the reservoir filling operation, in consequence of the geotechnical characteristics of the bank-slope materials. During large lake level decrease, the low hydraulic conductivity of the upper slope may contribute to increased movement in the onshore part of the slope. During large lake level increase, the higher permeability of the deposits of the lower slope, mostly constituted of ancient landslide deposits and slope debris, may facilitate acceleration in slope motion.

Data availability. The data are available from the authors upon request.

Author contributions. AT coordinated the work, contributed to the collection of the field data and wrote most of the manuscript. JG and TO carried out the pseudostatic and dynamic analysis of slope stability, PO carried out the static analysis and they helped to write the related chapters. PO also collected the extensometer data. NT and ZG calculated PSH and selected PGA, carried out the Vp and Vs30 velocity profiles and helped to write the related text. The discussion was agreed by all authors.

Competing interests. The authors declare that they have no conflict of interest.

Acknowledgements. We acknowledge two anonymous referees for their useful suggestions on a previous version of the paper. This study has been conducted in the framework of the NATO project SfP G4934 "Georgia Hydropower Security", of the International Lithosphere Program - Task Force II, of the European Space Agency project no. 32309 "Active tectonics and seismic hazard of southwest Caucasus by remotely sensed and seismological data" (Leader Alessandro Tibaldi) and of project 216758 of the Shota Rustaveli National Science Foundation.

Edited by: Paola Reichenbach

Reviewed by: two anonymous referees

\section{References}

Adamia, Sh., Lordkipanidze, M. B., and Zakariadze, G. S.: Evolution of an active continental margins exemplified by the alpine history of the Caucasus, Tectonophysics, 40, 183-199, 1977.

Adamia, Sh., Alania, V., Chabukiani, A., Chichua, G., Enukidze, O., and Sadradze, N.: Evolution of the Late Cenozoic basins of Georgia (SW Caucasus): a review, in: Sedimentary basin tectonics from the Black Sea and Caucasus to the Arabian Platform, edited by: Sosson, M., Kaymakçı, N., Stephenson, R., and Bergerat, F., Geological Society, London, Special Publication, 340, 239-259, 2010.

Adamia, Sh., Zakariadze, G., Chkhotua, T., Chabukiani, A., Sadradze, N., Tsereteli, N., and Gventsadze, A.: Geology of the Caucasus: A Review, Turk. J. Earth Sci., 20, 489-544, 2011.

Adamia, Sh., Alania, V., Tsereteli, N., Varazanashvili, O., Sadradze, N., Lursmanashvili, N., and Gventsadze, A.: Post-Collisional Tectonics and Seismicity of Georgia, in: Tectonic Evolution, Collision, and Seismicity of Southwest Asia: In Honor of Manuel Berberian's Forty-Five Years of Research Contributions, Geological Society of America Special Paper 525, 535-572, https://doi.org/10.1130/2017.2525(17), 2017.

Alania, V., Chabukiani, A., Chagelishvili, R., Enukidze, O., Gogrichiani, K., Razmadze, A., and Tsereteli, N.: Growth structures, piggyback basins and growth strata of Georgian part of Kura foreland fold and thrust belt: implication for Late Alpine kinematic evolution, in: Tectonic Evolution of the Eastern Black Sea and Caucasus, edited by: Sosson, M., Stephenson, R., and Adamia, Sh., Geological Society of London, Special Publications, 428, https://doi.org/10.1144/SP428.5, 2016.

Avagyan, A., Sosson, M., Karakhanian, A., Philip, H., Rebai, S., Rolland, Y., Melkonyan, R., and Davtyan, V.: Recent tectonic stress evolution in the Lesser Caucasus and adjacent regions, in: Sedimentary Basin Tectonics from the Black Sea and Caucasus to the Arabian Platform, edited by: Sosson, M., Kaymakci, N., Stephenson, R. A., Bergerat, F., and Starostenko, V., Geological Society, London, Special Publications, 340, 393-408, https://doi.org/10.1144/SP340.170305-8719/10, 2010.

Avdeev, B. and Niemi N. A.: Rapid Pliocene exhumation of the central Greater Caucasus constrained by lowtemperature thermochronometry, Tectonics, 30, TC2009, https://doi.org/10.1029/2010TC002808, 2011.

Banks, C., Robinson, A., and Williams, M.: Structure and regional tectonics of the Achara-Trialeti fold belt and the adjacent Rioni and Kartli foreland basins, Republic of Georgia, in: Regional and Petroleum geology of the Black Sea and Surrounding Region, Robinson, A. G., American Association of Petroleum Geologists Memoir no. 68, 331-336, 1997.

Bard, P.-Y.: Microtremor measurements: a tool for site effect estimation, in: The effects of surface geology on seismic motion, edite by: Irikura, K., Kudo, K., Okada, H., and Sasatani, T., Balkema, Rotterdam, 1251-1279, 1999.

Barrier, E. and Vrielynck, B.: Palaeotectonic Map of the Middle East, Atlas of 14 Maps, Tectonosedimentary-palinspastic Maps from Late Norian to Pliocene, Commission for the Geological Map of the World, Paris, 2008.

Bazzurro, P. and Cornell, C. A.: Deaggregation of seismic hazard, B. Seism. Soc. Am., 89, 501-520, 1999.

Beck, A. C.: Gravity faulting as a mechanism of topographic adjustment, New Zeal. J. Geol. Geoph., 11, 191-199, 1968. 
Beget, J. E.: Tephrochronology of antislope scarps on an alpine ridge near Glacier Peak, Washington, USA, Arctic Alpine Res., 17, 143-152, 1985.

Bonnefoy-Claudet, S., Cotton, F., Bard, P.-Y., Cornou, C., Ohrnberger, M., and Wathelet, M.: Robustness of the H/V ratio peak frequency to estimate 1D resonance frequency, in: Proceedings of the 3rd International Symposium on the Effects of Surface Geology on Seismic Motion, 2006.

CGS (Center Geodynamic Studies L.L.C.): Implementation of a complex engineering-geological survey of the left bank of the landslide in the reservoir area of arch dam LLC "Enguri HPP" and slope stability analysis, Technical report, Moscow, 2015.

Chigira, M. and Kiho, K.: Deep-seated rockslide avalanches preceded by mass rock creep of sedimentary rocks in Akaishi Mountains, central Japan, Engineering Geology, 38, 221-230, 1994.

Cotton, F., Scherbaum, F., Bommer, J. J., and Bungum, H.: Criteria for selecting and adjusting ground-motion models for specific target applications: applications to Central Europe and rock sites, J. Seismol., 10, 137-156, 2006.

Danciu, L., Kale, O., and Akkar, S.: The 2014 earthquake model of the Middle East: ground motion model and uncertainties, B. Earthq. Eng., 1-37, 2016.

Danciu, L., Şeşetyan, K., Demircioglu, M., Gülen, L., Zare, M., Basili, R., Elias, A., Adamia, S., Tsereteli, N., Yalçın, H., Asif Khan, M. U. M., Saya, M., Hessami, K., Rovida, A., Stucchi, M., Burg, J.-P., Karakhanian, A., Babayan, H., Avanesyan, M., Ammadli, T., Al-Qaryouti, M., Kalafat, D., Varazanashvili, O., and Erdik, M.: The 2014 earthquake model of the Middle East: seismogenic sources, B. Earthq. Eng., 16, 3465-3496, https://doi.org/10.1007/s10518-017-0096-8, 2018.

Deying, L., Kunlong, Y., and Chin, L.: Analysis of Baishuihe landslide influenced by the effects of reservoir water and rainfall, Environ. Earth Sci., 60, 677-687, https://doi.org/10.1007/s12665009-0206-2, 2010.

Evans, S. G. and Couture, R.: The 1965 Hope Slide, British Columbia; catastrophic failure of a sagging rock slope, Abstracts with Programs, Geological Society of America, 16-26, 2002.

Forte, A., Cowgill, E., Bernardin, T., Kreylos, O., and Hamann, B.: Late Cenozoic deformation of Kura fold-thrust belt, southern Greater Caucasus, Geological Society of American Bulletin, 122, 465-86, 2010.

Gobejishvili, R., Lomidze, N., and Tielidze, L.: Late Pleistocene (Würmian) Glaciations of the Caucasus, in: Developments in Quaternary Science, edited by: Ehlers, J., Gibbard, P. L., and Hughes, P. D., 15, 141-147, 2011.

Gutiérrez-Santolalla, F., Acosta, E., Rıos, S., Guerrero, J., and Lucha, P.: Geomorphology and geochronology of sackung features (uphill-facing scarps) in the Central Spanish Pyrenees, Geomorphology, 69, 298-314, 2005.

Hoek, E. and Bray, J. W.: Rock Slope Engineering, 3rd edn., The Institution and Metallurgy of Mining, London, 1981.

Jones, F. O., Embody, D. R., and Peterson, W. L.: Landslides along the Columbia River Valley, Northeastern Washington, US Geological Survey Professional Paper, 367 pp., 1961.

Kaczmarek, H., Tyszkowski, S., and Banach, M.: Landslide development at the shores of a dam reservoir (Włocławek, Poland), based on 40 years of research, Environ. Earth Sci., 74, 42474259, 2015.
Kavazanjian Jr., E., Matasovic, N., Hadj-Hamou, T., and Sabatini, P. J.: Geotechnical Engineering Circular No. 3: Design Guidance, Geotechnical Earthquake Engineering for Highways, vol. 1, Design Principles, No. Report No: FHWA-SA-97-076, 1997.

Kenney, T. C.: Slope stability in artificial reservoirs: influence of reservoir level, selected cases, and possible solutions, in: Proceedings of the meeting on the 1963 Vajont landslide, edited by: Semenza, E. and Melidoro, G., Ferrara, Cansiglio and Vajont, Grafica Ferrarese, Ferrara, Italy, 17-19 September 1986, 67-85, 1992.

Koçyiğit, A., Yılmaz, A., Adamia, S., and Kuloshvili, S.: Neotectonics of East Anatolia Plateau (Turkey) and Lesser Caucasus: Implication for transition from thrusting to strike-slip faulting, Geodin. Acta, 14, 177-195, 2001.

Macfarlane, D. F.: Observations and predictions of the behaviour of large, slow-moving landslides in schist, Clyde Dam reservoir, New Zealand, Eng. Geol., 109, 5-15, 2009.

Mahr, T.: Deep-reaching gravitational deformations of high mountain slopes, Bulletin of the International Association of Engineering Geology, 16, 121-127, 1977.

Maraschini, M. and Foti, S.: A Monte Carlo multimodal inversion of surface waves, Geophys. J. Int., 182, 1557-1566, 2010.

McCalpin, J.: Criteria for determining the seismic significance of sackungen and other scarplike landforms in mountainous regions, Techniques for Identifying Faults and Determining their Origins, U.S. Nuclear Regulatory Commission, Washington, 255-259, 1999.

McCalpin, J. P. and Irvine, J. R.: Sackungen at the Aspen Highlands ski area, Pitkin County, Colorado, Environ. Eng. Geosci., 1, 277290, 1995.

McGuire, R. K.: Computations of Seismic Hazard, Annali di Geofisica, 36, 181-200, 1995.

Meijers, M. J., Smith, B., Kirscher, U., Mensink, M., Sosson, M., Rolland, Y., Grigoryan, A., Sahakyan, L., Avagyan, A., Langereis, C., and Müller, C.: A paleolatitude reconstruction of the South Armenian Block (Lesser Caucasus) for the Late Cretaceous: Constraints on the Tethyan realm, Tectonophysics 644, 197-219, 2015.

Mosar, J., Kangarli, T., Bochud, M., Glasmacher, U. A., Rast, A., Brunet, M., and Sosson, M.: Cenozoic-Recent tectonics and uplift in the Greater Caucasus: a perspective from Azerbaijan, in: Sedimentary basin tectonics from the Black Sea and Caucasus to the Arabian Platform, edited by: Sosson, M., Kaymakçı, Stephenson, N. R., and Bergerat, F., Geological Society, London, Special Publication, 340, 261-279, 2010.

Nakamura, K.: On reservoir landslide, Bulletin on Soil and Water Conservation, 10, 53-64, 1990 (in Chinese).

Paronuzzi, P., Rigo, E., and Bolla, A.: Influence of fillingdrawdown cycles of the Vajont reservoir on Mt. Toc slope stability, Geomorphology, 191, 75-93, 2013.

Pasquaré Mariotto, F. and Tibaldi, A.: Inversion kinematics at deep-seated gravity slope deformations revealed by trenching techniques, Nat. Hazards Earth Syst. Sci., 16, 663-674, https://doi.org/10.5194/nhess-16-663-2016, 2016.

Pasquarè, F. A., Tormey, D., Vezzoli, L., Okrostsvaridze, A., and Tutberidze, B.: Mitigating the consequences of extreme events on strategic facilities: Evaluation of volcanic and seismic risk affecting the Caspian oil and gas pipelines in the Republic of Georgia, J. Environ. Manage., 92, 1774-1782, 2011. 
Pasuto, A. and Soldati, M.: Rock spreading, in: Landslide recognition, Identification, movement and causes, edited by: Dikau, R., Brunsden, D., Schrott, L., and Visen, M.-L., Wiley, Chichester, 122-136, 1996.

Pinyol, N., Alonso, E., Corominas, J., and Moya J.: Canelles landslide: modelling rapid drawdown and fast potential sliding, Landslides, 9, 33-51, https://doi.org/10.1007/s10346-011-0264$\mathrm{x}, 2012$.

Radbruch-Hall, D. H.: Gravitational creep of rock masses on slopes, in: Rockslides and Avalanches, vol. 1, edited by: Voight, B., Natural Phenomena, Developments in Geotechnical Engineering, 14, 607-657, 1978.

Rebai, S., Philip, H., Dorbath, L., Borissoff, B., Haessler, H., and Cisternas, A.: Active tectonics in the Lesser Caucasus: coexistence of compressive and extensional structures, Tectonics, 12, 1089-1114, 1993.

Reilinger, R. E., McClusky, S. C., Oral, M. B., King, R. W., Toksoz, M. N., Barka, A. A., Kinik, I., Lenk, O., and Sanli, I.: Global Positioning System measurements of present-day crustal movements in the Arabia-Africa-Eurasia plate collision zone, J. Geophys. Res., 102, 9983-9999, 1997.

Reilinger, R. E., McClusky, S. C., Vernant, P., Lawrence, S., Ergintav, S., Cakmak, R., Ozener, H., Kadirov, F., Guliev, I., Stepanian, R., Nadariya, M., Hahubia, G., Mahmoud, S., Sakr, K., Arrajehi, A., Paradissis, D., Al-Aydrus, A., Prilepin, M., Guseva, T., Evren, E., Dmirotsa, A., Filikov, S. V., Gomez, F., Al-Ghazzi, R., and Karam, G.: GPS constraints on continental deformation in the Africa-Arabia-Eurasia continental collision zone and implications for the dynamics of plate interactions, J. Geophys. Res., 111, B05411, https://doi.org/10.1029/2005JB004051, 2006.

Sajinkumar, K. S., Unnikrishnan Warrier, C., Muraleedharan, C., Shahul Hameed, A., Rani, V. R., Pradeepkumar, A. P., and Sundarajan, P.: A study on landslides and subsurface piping, facilitated by dykes, using vertical electrical sounding and $\delta \mathrm{O}^{18}$ and $\delta \mathrm{H}_{2}$ stable isotopes, B. Eng. Geol. Environ., 76, 1297-1306, 2017.

Schuster, R. L.: Reservoir-induced landslides, Bulletin of the International Association of Engineering Geology, 20, 8-15, 1979.

Schuster, R. L. and Wieczorek, G. F.: Landslide triggers and types, in: Proc. 1st European Conference on Landslides, edited by: Rybar, J., Stemberk, J., and Wagner, P., Prague, Czech Republic, Balkema Publishers, Taylor \& Francis, Prague, 59-78, 2002.

Semenza, E. and Ghirotti, M.: History of the 1963 Vaiont slide: the importance of geological factors, B. Eng. Geol. Environ., 59, 8797, 2000.

Şeşetyan, K., Danciu, L., Demircioğlu Tümsa, M. B., Giardini, D., Erdik, M., Akkar, S., Gülen, L., Zare, M., Adamia, S., Ansari, A., Arakelyan, A., Askan, A., Avanesyan, M., Babayan, H., Chelidze, T., Durgaryan, R., Elias, A., Hamzehloo, H., Hessami, K., Kalafat, D., Kale, O., Karakhanyan, A., Asif Khan, M., Mammadli, T., Al-Qaryouti, M., Sayab, M., Tsereteli, N., Utkucu, M., Varazanashvili, O., Waseem, M., Yalçın, H., and Tolga Yılmaz, M.: The 2014 seismic hazard model of the Middle East: overview and results, B. Earthq. Eng., 16, 3535-3566, 2018.

Solonenko, V. P.: Landslides and collapses in seismic zones and their prediction, Bulletin of the International Association of Engineering Geology 15, 4-8, 1977.
Sosson, M., Rolland, Y., Danelian, T., Muller, C., Melkonyan, R., Adamia, S., Kangarli, T., Avagyan, A., and Galoyan, G.: Subductions, obduction and collision in the Lesser Caucasus (Armenia Azerbaijan, Georgia), new insights, in: Sedimentary Basin Tectonics from the Black Sea and Caucasus to the Arabian Platform, edited by: Sosson, M., Kaymakci, N., Stephanson, R., Bergarat, F., and Storatchenoko, V., Geological Society of London Special Publication, 340, 329-352, 2010.

Tan, O. and Taymaz, T.: Active tectonic of the Caucasus: earthquake source mechanisms and rupture histories obtained from inversion of teleseismic body waves, Geological Society of America, special paper 409, 531-578, 2006.

Tibaldi, A. and Pasquarè, F.: Quaternary deformations along the "Engadine-Gruf tectonic system", Swiss-Italian border, J. Quaternary Sci., 23 475-487, 2008.

Tibaldi, A. and Tsereteli, N.: International effort tackles landslide hazards to keep the peace, Eos, 98, 24-28, https://doi.org/10.1029/2017EO065815, 2017.

Tibaldi, A., Ferrari, L., and Pasquarè, G.: Landslides triggered by earthquakes and their relationships with faults and mountain slope geometry: an example from Ecuador, Geomorphology, 11, 215-226, 1995.

Tibaldi, A., Rovida, A., and Corazzato C.: A giant deep-seated slope deformation in the Italian Alps studied by paleoseismological and morphometric techniques, Geomorphology, 58, 27-47, 2004.

Tibaldi, A., Corazzato, C., Rust, D., Bonali, F. L., Mariotto, F. P., Korzhenkov, A. M., Oppizzi P., and Bonzanigo, L.: Tectonic and gravity-induced deformation along the active Talas-Fergana Fault, Tien Shan, Kyrgyzstan, Tectonophysics, 657, 38-62, 2015.

Tibaldi, A., Alania, V., Bonali, F. L., Enukidze, O., Tsereteli, N., Kvavadze, N., and Varazanashvili, O.: Active inversion tectonics, simple shear folding and back-thrusting at Rioni Basin, Georgia, J. Struct. Biol., 96, 35-53, 2017a.

Tibaldi, A., Russo, E., Bonali, F.L., Alania, V., Chabukiani, A., Enukidze, O., and Tsereteli, N.: 3-D anatomy of an active faultpropagation fold: a multidisciplinary case study from Tsaishi (Georgia), western Caucasus, Tectonophysics, 717, 253-269, 2017b.

Tsereteli, N., Tibaldi, A., Alania, V., Gventsadse, A., Enukidze, O., Varazanashvili, O., and Müller B. I. R.: Active tectonics of central-western Caucasus, Georgia, Tectonophysics, 691, 328344, 2016.

Varazanashvili, O., Tsereteli, N., Bonali, F. L., Arabidze, V., Russo, E., Pasquarè Mariotto, F., Gogoladze, Z., Tibaldi, A., Kvavadze, N., and Oppizzi, P.: GeoInt: the first macroseismic intensity database for the Republic of Georgia, J. Seismol., 1-43, https://doi.org/10.1007/s10950-017-9726-5, 2018.

Varnes, D. J., Coe, J. A., Godt, J. W., Savage, W. Z., and Savage, J. E.: Measurement or ridge-spreading movements (sackungen) at Bald Eagle Mountain, Lake County, Colorado, II: continuation of the 1975-1989 measurements using a Global Positioning System in 1997 and 1999, U.S. Geological Survey, Open file report 00205, 2000.

Varnes, D. J., Radbruch-Hall, D. H., and Savage, W. Z.: Topographic and structural conditions in areas of gravitational spreading of ridges in the western United States, U.S. Geological Survey Professional Paper, 1496, 28 pp., 1989. 
Varnes, D. J., Radbruch-Hall, D. H., and Varnes, K. L.: Measurement of ridge spreading movements (sackungen) at Bald Eagle Mountain, Lake County, Colorado, 1975-1989, U.S. Geological Survey, Open File Report, 90-543, 13 pp., 1990.

Vincent, S. J., A. Carter, V. A. Lavrishchev, S. P. Price, T. G. Barabadze, and Hovius, N.: The exhumation of the western Greater Caucasus: a thermochronometric study, Geological Magazine, 148, 1-21, 2011.

Vincent, S. J., Morton, A. C., Carter, A., Gibbs, S., and Teimuraz, G. B.: Oligocene uplift of the Western Greater Caucasus: An effect of initial Arabia-Eurasia collision, Terra Nova, 19, 160-166, 2007.
Zangerl, C., Eberhartd, E., and Perzlmaier, S.: Kinematic behaviour and velocity characteristics of a complex deep-seated crystalline rockslide system in relation to its interaction with a dam reservoir, Eng. Geol., 112, 53-67, 2010.

Zhu, D., Yan, E., Hu, G., and Lin, Y.: Revival deformation mechanism of Hefeng Landslide in the Three Gorges Reservoir based on FLAC3D software, Procedia Engineer., 15, 2847-2851, 2011.

Zolotarev, G. S., Makhorin, A. A., and Federenko, V. S.: Geological map of left bank of river Enguri, upper part of Enguri HPP, Scale $1: 2500$, Ministry of Energy, CCCP, 1968. 